\title{
Declared War and American Victory: A SEARCh FOR EFFECTIVE COMMITMENT
}

\section{Slade Mendenhall*}

\begin{abstract}
This Article argues that the act of formally declaring war entails a measure of explicit commitment on the part of American political actors that raises the cost of failure and motivates politicians to see engagements through to a decisive end, fulfilling the role of a contract or institutional commitment device. It argues that undeclared conflicts, lacking such a device, are more likely to end on less decisive and less favorable terms to the United States. On this basis, it explains the emergence of a decades-long trend of protracted, unsuccessful, and indecisive military engagements by the United States as having emerged from the erosion of a constitutionally established separation of powers with respect to the initiation and administration of foreign military conflicts. In defense of this theory, it uses case studies to assess the relevance of its predictions and to weigh potential objections involving selection bias and imperfect information.
\end{abstract}

KEYWORDS

Declare War Clause, War Powers, Congressional Oversight, Public Choice, Constitutional Economics

\section{CONTENTS}

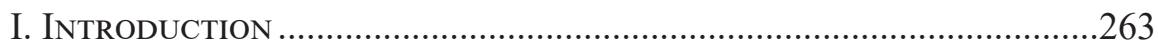

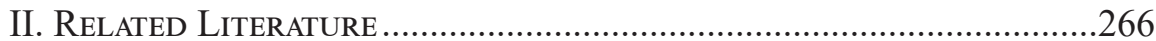

III. Origins of the War Powers Clause ............................................22

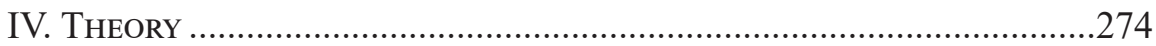

A. The Institution of Declared War .............................................2274

B. Undeclared Conflicts as Institutional Failure ............................282

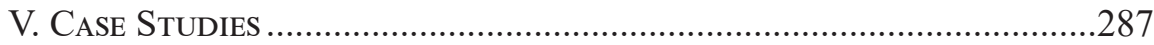

* Robert A. Levy Fellow, Antonin Scalia Law School, George Mason University, Arlington, VA and Department of Economics, George Mason University, Fairfax, VA. Contact: smenden2@gmu.edu.

The author would like to thank Christopher J. Coyne, Peter T. Leeson, Michael Greve, Garrett Wood, Bryan Cutsinger, and participants at the 2017 Annual Meeting of the Public Choice Society for helpful comments and suggestions during the researching and writing of this article. The usual disclaimers apply 
A. Declared Wars ......................................................................28

i. The American Revolution .........................................................28

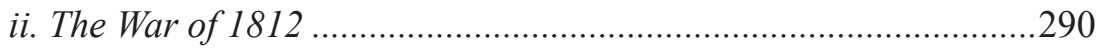

iii. The Mexican-American War...................................................294

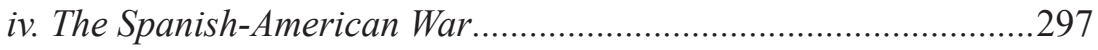

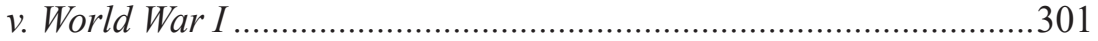

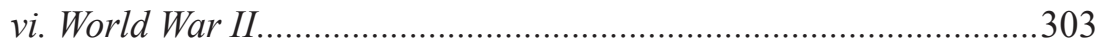

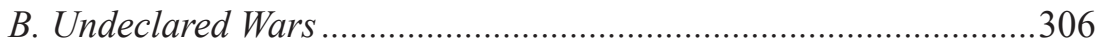

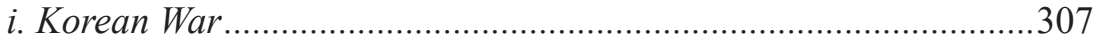

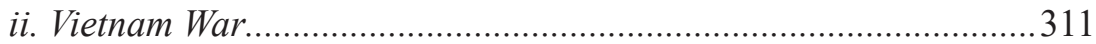

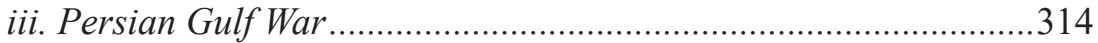

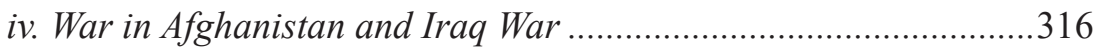

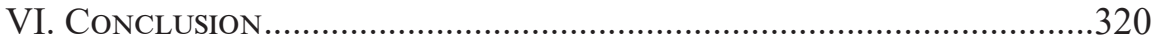




\section{INTRODUCTION}

In the two-hundred-and-forty years since the Declaration of Independence, the United States Congress or its antecedent, the Second Continental Congress, have formally declared war eleven times against ten countries in six separate wars: the American Revolution (1776), War of 1812 (1812), Mexican-American War (1846), Spanish-American War (1898), World War I (1917), and World War II (1941). The United States (or the colonies that would soon comprise it) decisively won five of them and concluded the other (War of 1812) in a favorable draw. In fourteen instances, the U.S. engaged in a significant military conflict with congressional approval but without a formal declaration. In seven other cases, the U.S. Congress funded military engagements led by the United Nations without either formally declaring war or engaging its own military. The record for these undeclared or U.N.-led conflicts has been more mixed, occasionally resulting in clear victories but often leading to costly and prolonged engagements without a decisive or favorable result. Despite the "Powell Doctrine" having instilled in modern American military leadership the values of overwhelming force, well defined goals, and clear exit strategies, ${ }^{1}$ American conflicts in recent decades have shown anything but.

The contrasting outcomes across these two categories invite this article's hypothesis: that the act of formally declaring war raises the cost of failure and mission creep such that legislators are more likely to press for a swifter resolution of conflict and a more decisive victory. This article views a congressionally approved, formal declaration of war as carrying certain costs and commitments for legislators. In committing the United States to war, they not only ask for certain contributions of both lives and wealth from American citizens; they put their own reputations at stake in the process, making themselves vulnerable to public backlash should the war become too costly and unpopular.

Viewing institutional commitment devices as arrangements that enhance performance by aligning costs and benefits, this article applies theoretical understandings of such arrangements in the context of wartime politics, arguing that with declarations as commitment devices attaching them to the outcome of a war, legislators will be less capable of treating war as a strictly executive affair and less prone to shifting blame for unsuccessful endeavors onto the executive. Legislators will thus apply greater pressure to bureaucrats, the executive, and the military to satisfy popular tastes for security and victory relative to that which would be exerted in the absence of a declaration. Formal declarations thus function much like written contracts in improving the fulfillment of commitments and in serving as reference points for parties' senses of entitlement. ${ }^{2}$ Even in the presence of sovereign immunity and the inability of the public to seek formal redress for the government's failure to meet its commitments, it is argued here that the act of making an explicit,

\footnotetext{
See generally, Colin L. Powell, U.S. Forces: Challenges Ahead, 71 ForeIgn Aff. 32 (1992).

2 For a summary and update of the classical conception of contracts, see Patrick Bolton \& Mathias Dewatripont, Contract Theory (2005). For an argument on the effect of moral obligations motivating contract fulfillment, see Charles Fried, Contract as Promise: A Theory of Contractual Obligation (1981). For the theory of contracts as reference points, see Oliver Hart \& John Moore, Contracts as Reference Points, 123 Q. J. ECON. 1 (2008).
} 
written commitment in conjunction with the threat of electoral punishment proves sufficient to motivate politicians to see wars through to more decisive and favorable ends. The effect of that written commitment, however, depends upon loyal, continued adherence to the constitution's requirements for making war. As Daryl Levinson has written, "Formal constitutional entrenchment is not sufficient to create functional entrenchment because formal, legal barriers may be ignored, opportunistically revised or overriden" and "[a]n effective system of constitutional law-one that can serve as a mechanism of political commitment-thus depends on the success of an underlying sociopolitical commitment to play by the constitutional rules." ${ }^{3}$ In making this argument, I adopt a public choice approach grounded in rational choice, politics-as-exchange, and methodological individualism. ${ }^{4}$ In short, partisanship and the notion of Congress acting qua institutum may be superficially descriptive, but, in the limit, only individuals choose.

For students and practitioners of constitutional law and constitutional economics, this perspective on the problem of political commitment in the context of war invites us to consider a potential contractual incompleteness in our constitutional separation of powers and how that incompleteness can result in poorly defined political property rights, precipitating ex post reallocations of powers between branches that, though optimal from the standpoint of politicians, may impose considerable costs on the population at large. This does not mean that political actors bargaining away from constitutional entitlements is never, on net, socially optimal; experience may reveal Pareto efficient departures from the Founders' initial constitutional allocations. Nor, however, does it mean, as Aziz Huq comes close to saying, that such departures generally pass the costbenefit test or are presumably born of the wisdom of experience; ${ }^{5}$ many are very arguable as rent-seeking made intransigent by the logic of concentrated benefits and dispersed costs. Which has transpired in a particular case rent-seeking or Pareto improvement is an empirical question. On occasion, the Supreme Court has strictly limited institutional bargains on hyper-formalist grounds, ${ }^{6}$ but the general tendency is to allow them subject to certain limitations, giving rise to the delegation doctrine in its various statutory permutations ${ }^{7}$, the "clear statement rule" for Spending Clause

3 Daryl J. Levinson, Parchment and Politics: The Positive Puzzle of Constitutional Commitment, 124 Harv. L. Rev. 657, 698 (2011).

4 See generally, James M. Buchanan \& Gordon Tullock, The Calculus of Consent: Logical Foundations of Constitutional Democracy, Chs. 2-4 (Liberty Fund 1999) (1962). For elaborations on its theoretical framework, see Geoffrey Brennan, Politicsas-Exchange and the Calculus of Consent, 152 Рuв. Сногсе 351 (2012). See also Viktor J. Vanberg, Methodological and Normative Individualism in "The Calculus", 152 PuB. Сноice 381 (2012).

5 Aziz Huq, The Negotiated Structural Constitution, 114 Colum. L. Rev. 1595 (2014).

$6 \quad$ E.g., INS v. Chadha, 462 U.S. 919 (1983); Clinton v. City of New York, 524 U.S. 417 (1998).

7 See, e.g., Mistretta v. United States, 488 U.S. 361 (1989); American Power \& Light Co.v. SEC, 329 U.S. 90, 105 (1946); Opp Cotton Mills, Inc. v. Administrator, Wage and Hour Div. of Dept. of Labor, 312 U.S. 126, 145 (1941); J.W. Hampton, Jr., \& Co. v. United States, 276 U.S. 394, 406 (1928). But see A.L.A. Schecter Poultry Corp. v. United States, 295 U.S. 495 (1935); Panama Refining Co. v. Ryan, 293 U.S. 388, 421 (1935). 
statutes ${ }^{8}$, the functionalist reasoning of Noel Canning, ${ }^{9}$ etc. It seems incontrovertible to say that outright inter-branch conspiracies that benefit politicians at the public's expense should be blocked. On the other hand, we wish to preserve textually permissible and institutionally sensible bargains, net of the cost of lost transparency and accountability.

Perhaps most importantly, this analysis also breaks new ground by pushing legal scholarship on declarations of war beyond historical debates (reviewed below) over what was intended by the Founders in the writing of Article I, Section 8 of the U.S. Constitution and toward an arguably more important question for contemporary purposes: what the substantive effect of formal declarations might be on relevant actors' incentives and behavior. If, as scholars of constitutional economics have long held ${ }^{10}$, the terms and structure of constitutional relationships have a meaningful effect on actors' behavior, then it would seem both plausible and highly significant that changes which radically alter the nature of such relationships even temporarily, in a time of crisis should affect individuals' choices on the margin. On that premise, it is reasonable to expect that a systematic change of constitutional practice from using formal declarations and the expansion of powers that they entail to abandoning declarations altogether should bear upon the incentives of policy makers. The framers of the Constitution, it is argued here, understood the implications that separation of powers would have for war policy and crafted the uniquely American system of legislative declaration and executive prosecution of war accordingly. Recent generations' abandonment of formal declarations has been more tacitly accepted than rationally advocated, and perhaps irreversibly so, but before an explicit constitutional grant of power to one branch is permanently traded to another and the constitutional model of war declaration is relegated to history books, it is worth asking whether the purported public benefits of the trade exceed its costs.

The following section presents a brief review of the relevant literatures in law, political science, political theory, and public choice. Section Three offers a very brief intellectual history of the origins of the Declare War Clause. Section Four describes the institution of declaring war, presents the theory of formal declarations of war as commitment devices, and models the institutional conditions that prevail with and without explicit declarations, arguing that the issue at the root of common modern complaints about prolonged and indecisive military conflicts is an inadequate stricture in the constitutional assignment of political property rights and prohibitions of ex post renegotiations between branches of government. Section Five offers a series of case studies, comparing declared and undeclared wars to illustrate the theory and determine whether ready objections to this view sustain the weight of the evidence. Section Six concludes.

$8 \quad$ E.g., Atascadero State Hosp. v. Scanlon, 473 U.S. 234, 255 n. 7 (1985) (Brennan, J., dissenting).

$9 \quad$ N.L.R.B. v. Noel Canning, 573 U.S. 513 (2014).

10 See generally, James M. Buchanan \& Gordon Tullock, The Calculus of Consent: Logical Foundations of Constitutional Democracy (Liberty Fund 1999) (1962); James M. Buchanan, Logical Foundations of Constitutional Liberty (1999); James M. Buchanan, Federalism, Liberty, and the LaW (2001); Robert D. Cooter, The Strategic Constitution (Princeton U. Press 2002) (2000). 


\section{RELATED LITERATURE}

In the argument of this article, we go against the trajectory of thought on the subject since the signing of the Constitution. In that time, the prevailing view has shifted from declarations of war being considered too obviously necessary to merit debate to being considered too obviously superfluous. James Madison asserted in Federalist No. $41^{11}$ that the power of declaring war was so selfevidently necessary that it was superfluous to argue the point. Professor Clyde Eagleton, observing emerging practices and opinions in 1938, expressed doubt that war would ever be declared again and that "the declaration of war seems to be regarded by some as an anachronism to be discarded." 12 The radical change in American intellectuals' views on the subject over that 150 year period can be traced by periodic publications. Noted jurist Henry Wheaton asserts clearly that declarations of war to one's enemy are superfluous as a matter of international law. ${ }^{13}$ Rather, he makes a pragmatic argument for declarations to one's own people based not in Madison's intention of restraining the executive but a pragmatic case for giving fair warning to merchants, "the instruction and direction of the subjects of the belligerent State," and the simplification of subsequent peace conferences. ${ }^{14}$ Eagleton asks the purpose of a formal declaration of war and, prioritizing the resolution of related legal issues, answers that it satisfies the demand for a specific "date upon which the metamorphosis from peace to war takes place." 15

Modern literature on formal declarations of war continues to be predominated by the legal scholarship, with political science and theory playing secondary roles. The most thorough legal analysis of the subject has been conducted by Fisher $^{16}$, who argues that modern American politicians' approaches to entering war have been contrary to those of America's Founding Fathers both in theory and practice. He conducts a comparative analysis of American conflicts from the founding through the presidency of Barack Obama, with particular focus on the executive branch's aggregation of war powers over that period and Congress's willingness to surrender those war powers guaranteed to it by the language of the Constitution. Contrary to the stated intention of the War Powers Resolution of 1973, he sees it and other modern legislative actions on war powers as attempts by Congress to appear concerned with the loss of its war powers rather than as genuine efforts to reassert those powers. Prakash details three approaches to understanding the war clause of the Constitution - categorical, pragmatic, and formalist - and analyzes the merits of each interpretation, landing ultimately in favor of the categorical interpretation, which gives Congress "power to control all decisions to enter war." ${ }^{17}$ Delahunty and Yoo, in response to Prakash, argue that the war clause was designed only to

\footnotetext{
The Federalist No. 41 (James Madison) (Gideon ed., Liberty Fund, 2001) (1788).

12 Clyde Eagleton, The Form and Function of the Declaration of War, 32 Am. J. INT'L. L. 19 (1938). To date, Professor Eagleton has been correct, with the sole exception of World War II.

13 Henry Wheaton, Elements of International LaW 214 (1836).

$14 \quad I d$. at 213.

15 Eagleton, supra note 14, at 229.

16 Louis Fisher, Presidential War Powers (3d. ed., 2013).

17 Saikrishna Prakash, Unleashing the Dogs of War: What the Constitution Means by 'Declare War,'93 Cornell L. Rev. 45 (2007).
} 
"regulate the relations between the United States and other states" rather than to in any way regulate the division of power between the branches of the federal government. ${ }^{18}$ Campanelli et al. note that no one among the Founders denied that the president might respond militarily to imminent attack requiring a defensive response, but they find it unambiguous in the record of late eighteenth and early nineteenth century debates, communications, ratifying conventions, and Supreme Court opinions that Congress alone held "the power to make war." ${ }^{19}$ And Paulsen, arguing more broadly that the executive power over warmaking is at a historical high with Congress' grants of unprecedented power to the president in the War on Terror, nonetheless notes that the power to declare war is not the power to manage it and that the two should not be confused.$^{20} \mathrm{We}$ do not dispute this but rather argue that the two powers are functionally linked by declarations giving legislators a greater personal stake in military conflict and forestalling their attempts to shift all accountability for war onto the executive.

In political science and theory, the most extensive recent treatments have been by Hallett, who defends the practice on the basis of preferences for peace and limited government ${ }^{21}$ but whose subsequent writing is pessimistic on the prospects of ever reestablishing the incentives to revive the formal declaration process. ${ }^{22}$

The assertion that declarations have a positive effect on the outcomes of wars is either absent from or in contradiction to all existing literature on the subject. Most writers on the subject have been silent on declarations' effect on the outcomes of wars. Hallett, a defender of formal declarations, denies that declarations affect the contest of war: "from the legal perspective, declarations of war affect primarily the condition of war, not the contest, the declaration's specific juridical functioning being to establish the legal condition of war by voiding contracts and treaties, triggering the rights of neutrals, and activating the other provisions of the law of war." ${ }^{23}$ Accordingly, most defenders of the custom have focused their attention on normative arguments grounded in preferences for limited government, ${ }^{23}$ chivalrous "fair warning" to an enemy, ${ }^{24}$ clarifying ex post legal questions, ${ }^{25}$ religious beliefs,${ }^{26}$

18 Robert J. Delahunty \& John Yoo, Making War, 93 Cornell L. Rev. 123 (2007). A surprising interpretation, given that the overriding purpose of the Constitution itself was to regulate the division of power between branches of the federal government and not between the United States and other states.

19 M. Andrew Campanelli et. al., The Original Understanding of the Declare War Clause, 24 J.L. \& PoL. 49 (2008).

20 Michael Stokes Paulsen, The War Power, 33 Harv. J.L. \& Pub. Pol’y 113 (2010).

21 Brien Hallett, The Lost Art of Declaring War(1998).

22 Id. at 87; Brien Hallett, Declaring War: Congress, the President, and What the Constitution Does Not Say (2012).

23 Hallett supra note 23; Hallett supra note 24; Louis Fisher, Presidential War Powers (3d. ed., 2013).

24 Thucydides, History of the Peloponnesian War, (Richard Crawley trans., Longmans, Green, and Co. 1874); Sir John Frederick Maurice, Hostilities Without Declaration Of War: An Historical Abstract of the Cases in Which Hostilities Have Occured Between Civilized Powers Prior to Declaration or Warning (Nabu Press 2012) (1871).

25 Clyde Eagleton, The Form and Function of the Declaration of War, 32 Am. J. InT'L. L. 19 (1938).

26 Deut. 20:10-12 (King James); Judges 11:1-32 (King James). 
diplomatic clarity of intentions ${ }^{27}$, courtesy to merchants, instruction of the domestic population $^{28}$, and general preferences for peace over war. ${ }^{29}$

Critics of the formal declaration process, having predominated the last century of scholarship on the subject, follow primarily in the tradition of Cornelius van Bynkershoek, ${ }^{30}$ who described the act of formal declaration as a largely hollow process designed "to render victory more honourable and glorious." William Edward Hall echoed this view, writing that "any sort of previous declaration... is an empty formality unless the enemy must be given time and opportunity to put himself in a state of defence, and it is needless to say that no one asserts such a quixotism to be obligatory." ${ }^{31}$ Along these lines, it can be generally asserted that, far from seeing a positive strategic value to declarations, critics of the process tend to view them as dispensing with a valuable element of surprise at the onset of war.

A rare attempt to integrate the insights of law and economics to the issue of declaring war is by Sidak, who, adapting the insights of the Coase Theorem, cites reduced monitoring costs and enhanced political accountability in formally declared versus undeclared wars. ${ }^{32} \mathrm{His}$ extensive analysis and application to the Persian Gulf War offers a normative interpretation of the War Clause structured upon a positive analysis of the separation of powers. In contradistinction to the Coase Theorem's assertion that the establishment of legal rules and property rights reduces transaction costs and facilitates bargaining, Sidak argues for an "Inverse Coase Theorem" in which "monitoring costs are reduced, and political accountability enhanced, by prohibiting bargains that alter the Constitution's formal allocation of rights of decision among political actors. ${ }^{\prime 33}$ Given that the executive and legislative branches make bargains over that which belongs to a third party (the public), Sidak argues, the failure to explicitly allocate those powers between the two branches in greater detail allows them to lay considerable costs on the public while preventing the public from effectively discerning which branch is accountable for the increasing burden of the war. Sidak's characterization of the problem presented by undeclared conflicts is accepted here and extended through the application of choice theory and the literature on contracts and commitment devices.

An extensive literature in institutional economics views the nature and implications of institutional commitment devices as arrangements that enhance

27 Hugo Grotius, The Rights of War and Peace 321 (A. C. Campbell trans., M. Walter Dunne 1901) (1625); Convention (III) relative to the Opening of Hostilities. The Hague, 18 October 1907; Maurice supra note 26 at 3; see Henry Wheaton, Elements of INTERNATIONAL LAW 213 (1836).

28 See Henry Wheaton, Elements of International Law 229 (1836).

29 Hallett, Declaring War, supra note 24; Hallett, The Lost ART , supra note 23; Cicero, De Officiis i. II. 36, iii. 23-35; cf. De Republica ii. 17; G. A. Harrer, Cicero on Peace and War, 14 Classical J. 26, 38 (1918).

30 Cornelius van Bynkershoek, Quaestionum Juris Publici Liber Duo, 14 (Frank Tenney trans., 1930).

31 William Edward Hall, A Treatise on International Law (A. Pearce Higgins, 8th ed., Oxford Univ. Press 1924) (1880).

32 J. Gregory Sidak, To Declare War, 41 Duke L.J. 27 (1991); J. Gregory Sidak, The Inverse Coase Theorem and Declarations of War, 41 DukE L.J. 325 (1991).

33 Sidak, supra note 34 at 326. 
performance by establishing shared goals, costs, and benefits. ${ }^{34}$ The fundamental importance of institutions in establishing credible commitment is addressed by North. ${ }^{35}$ Noting that commitment is not the sole function of institutions and should not be the only standard by which they are measured, he nonetheless cites it as "overwhelmingly the most pressing issue." Shepsle specifies this further by arguing that commitment can be credible in one of two ways: the motivational or the imperative. ${ }^{36}$ Motivational credibility reinforces commitment by making actors want to fulfill their terms at the point of transaction. Imperative credibility does so through coercion or the removal of actors' discretion. The role of declarations as argued here can be thought of as having the same motivational/imperative characteristics of legislation more generally in the public choice literature: voters prefer legislators who are intrinsically motivated to fulfill the commitments at a minimum of costly punishment but are willing to vote politicians out if they fail to deliver.

A theory of legislative and executive commitment playing instrumental roles in foreign policy has already been detailed by Martin, who argues that for democracies, legislative integration into cooperative diplomatic arrangements is instrumental to determining the level of commitment to those arrangements. ${ }^{37}$ She presents two mechanisms by which this is made true: (i.) legislatures' power to reclaim authority from the executive or to refuse to implement international arrangements and (ii.) indirect means of control through funding and the obstruction or delay of necessary ratifications. In this theory, she upholds a conception of legislative-executive relations as an exchange relationship and highlights the need for "institutions that allow both branches to benefit from international cooperation. ${ }^{" 38}$ Leeds likewise argues that domestic institutional arrangements create incentives that have significant consequences for the success of international cooperation. ${ }^{39}$ These views are extended here with one modification: the contention that the same principles apply in instances of international conflict as in international cooperation. Seeing formally declared war as a political condition as well as a contest, it assumes the legislature to be no less relevant in determining the degree of political commitment to the prosecution of war than it would be in determining the commitment to peace.

A formal declaration of war is presented as a commitment device that better ensures the successful resolution of international conflict.

34 Douglass C. North, Institutions and Credible Commitment, 149 J. Institutional \& TheOretical ECON. 11 (1993); Lisa L. Martin, Theoretical Framework: Legislatures, Executives, and Commitment, in Democratic Commitments: Legislatures AND International CoOperation 21 (2000); Jeffrey K. Staton \& Christopher Reenock, Substitutable Protections: Credible Commitment Devices and Socioeconomic Insulation, 63 Pol. Res. Q. 115 (2010).

35 North, supra note 36.

36 Kenneth Shepsle, Discretion, Institutions, and the Problem of Government Commitment, in Social Theory for a Changing Society 245 (Pierre Boureau \& James S. Coleman eds., 1991).

37 Lisa L. Martin, Theoretical Framework: Legislatures, Executives, and Commitment, in Democratic Commitments: Legislatures and International Cooperation, 21 (2000).

$38 \quad$ Id. at 23.

39 Brett Ashley Leeds, Domestic Political Institutions, Credible Commitments, and International Cooperation, 43 Ам. J. PoL. ScI., 979 (1999). 
This theory also puts forward a new application of the literature on elected officials' responsiveness to voters' preferences. An existing literature argues that elected officials face pecuniary and non-pecuniary costs if they fail to deliver what they promise and will thus strive to avoid those costs by conforming to voters' values and expectations. ${ }^{40}$ Downs argues that politicians "act solely in order to attain the income, prestige, and power which come from being in office... their only goal is to reap the rewards of being in office per se" and contends that this goal is equivalent to maximizing voter support. ${ }^{41}$ Maskin and Tirole view this as sufficient to eliminate the moral hazard concerns that come with permanently appointed officials and to shape officials' behavior in accordance with voters' values. Weighing the costs and benefits of direct democracy, representative democracy, and permanent appointments, they conclude that the welfare-maximizing option for the public is, ceteris paribus, for decisions resulting in large legacy payoffs to be handled by elected representatives who face the prospect of reelection. They specifically cite the choice of whether to enter war as an instance of such a decision. Though this does not, of itself, imply anything as to the superiority of a legislatively declared and managed war versus one spearheaded by the executive (since both are elected officials), it does justify the assumption of a significant interrelationship between, on the one hand, voters' welfare and, on the other, elected representatives playing a greater role in the decision of whether or not to engage in war. It is no great logical leap to assume, based on this, that the greater the share of elected officials who play a role in the decision to enter war, the greater the share to whom these incentives apply.

Also pertinent is the copious literature on civilian control of military policy and operations. Naturally, the arguments made here take much for granted in assuming that civilian leadership matters and has a substantive effect on the conduct of war. Huntington traces the evolution of civilian control of the American military, arguing that its modern form is more a product of extra-constitutional political practice than of the framers' design. ${ }^{42}$ The assignment of an executive office of "Commander in Chief" rather than a specific set of tasks, he argues, has led to complicated historical questions and inter-branch contests for power over military affairs ${ }^{43}$ Later writings by Huntington, however, still portray a viable effect of civilian control, arguing that it is fostered by interbranch competition within the military ${ }^{44}$ and that sharp distinctions between the military and civilian spheres were crucial to the military "internalizing" civilian control and maintaining favorable relations with civilian functions of the state. ${ }^{45}$ Quite contrary to the perspective of my arguments,

40 Anthony Downs, An Economic Theory of Democracy (1957); Eric Maskin \& Jean Tirole, The Politician and the Judge: Accountability in Government, 94 Am. Econ. Rev. 1034 (2004); Claire S. H. Lim, Preferences and Incentives of Appointed and Elected Public Officials: Evidence from State Trial Court Judges, 103 Am. Econ. Rev. 1360 (2013).

41 Downs, supra note 42, at 28-31.

42 Samuel P. Huntington, Civilian Control and the Constitution, 50 Am. Pol. ScI. Rev. 676 (1956).

43 Id. at 693-99.

44 Samuel P. Huntington, Interservice Competition and the Political Roles of the Armed Services in Total War and Cold War:Problems in Civilian Control of the MilitaRY (Harry L. Coles ed., 1962).

45 Samuel P. Huntington, The Soldier and the State: The Theory and Politics of Civil Military Relations (1964). 
Damrosch has argued that there is a general trend in constitutional democracies toward parliamentary control over war and peace decisions and that Congress has asserted more power in this arena over time. ${ }^{46} \mathrm{Her}$ argument, however, is hard to reconcile with the facts as described here. To the matter of how congressional resignation from this area might have substantive effects, Sechser demonstrates through quantitative analysis that states with strong civilian control over the military are, on average, less prone to initiate military action than states without it, suggesting that, consistent with my argument, reduced civilian involvement might lead to more frequent engagements. ${ }^{47}$ Last but not least, Yoo encourages further examination of civilian-military relations within the framework of administrative law and principle-agent theory, citing the president's removal authority as vesting him with considerable control over military conduct. ${ }^{48}$ And Powell's account, as a former chairman of the Joint Chiefs of Staff, commends such a perspective, noting generals' cognizance of Secretary of Defense Dick Cheney's willingness to fire generals during the administration of George H.W. Bush. ${ }^{49}$ Though debates persist as to the proper policy approach and the right balance of civilian and military control, there is a broad, if tacit, acceptance of the premise that civilian policy matters and can have a substantive effect on military outcomes.

Finally, in accordance with the view that declarations do not affect the contest of war, a contrary explanation for the United States' greater success in declared wars is selection bias. This view contends that American politicians choose to formally declare war only where and when they believe that they face a high probability of success. This hypothesis thus invites us, as we review the historical record of declared versus undeclared conflicts, to consider whether cases in which military engagements are undeclared would have appeared to politicians at the onset of conflict as more daunting, their outcomes less certain. If success can be said to have been generally viewed as less probable at the onset of undeclared wars than in declared ones, then this critique may carry considerable weight. If not, then the ex post effects of declarations on political incentives and commitment must be viewed with interest, suggesting a worthwhile research agenda into the constraints and incentives that formal declarations provide.

\section{Origins of the War Powers Clause}

The Founders' embrace of separations-of-powers was as radical a departure from common practice in war declaration as it was in so many other aspects of governance. They were not, however, working against a blank slate. As noted above, many revered political and legal theorists through the ages had addressed the question of war declaration, from Thucydides to Grotius, van Bynkershoek, and

$46 \quad$ Lori F. Damrosch, Is There a General Trend in Constitutional Democracies Toward Parliamentary Control Over War-and-Peace Decisions?, 90 Proc. Ann. Meeting Am. Soc. INT'L L. 36 (1996).

47 Todd S. Sechser, Are Soldiers Less War-Prone Than Statesmen?, 48 J. Conflict Res. 746 (2004).

48 John Yoo, Administration of War, 58 DuKe L.J. 2277 (2009).

49 Colin Powell, An Exchange on Civil-Military Relations, 36 NAT'L InT. 23, 23 (1994). 
others with whom the Founders were surely familiar. ${ }^{50}$ Locke, in his Two Treatises, distinguished three categories of governmental powers legislative, executive, and federative and placed the "power of war and peace" and other matters of foreign relations among the federative.$^{51}$ Locke, however, noted that the federative and executive powers were "almost always united," stressing that they "are hardly to be separated and placed... in the hands of distinct persons," as both require the "force of society." 52 And a generation later, in Montesquieu, the distinction was erased entirely, leaving only the legislative power and a dual executive power over civil and international laws. ${ }^{53}$ Going still further, Blackstone, in his Commentaries, warned that subjecting foreign affairs to the many wills of democracy would lead to indecisiveness and considerable danger. ${ }^{54}$ The Founders' great regard for these theorists notwithstanding, they clearly elected not to follow their trajectory when it came to assigning the power to declare war.

The Founders' division of war powers across branches of government harkened more to their admiration for the republics of Antiquity than for the Englightenment theorists. Both Greece and Rome, in their experiences with representative government, divided war powers across separate bodies. In Ancient Athens, the Assembly (ecclesia) was reponsible for declaring war on behalf of the city, overseeing military strategy, and electing generals and other military officials. ${ }^{55}$ And Sparta, though initially having granted war declaration powers to its dual kings, stripped them of that right from the time of the Persian wars, asserting greater legislative control. ${ }^{56}$ The Founders, however, to the extent that they were influenced by the ideal of Greek politics, looked to the more mixed democracy of Solonian Athens than the unlimited majoritarianism of other eras of Athens or to the statism of Sparta, and they seemed to favor the example of Rome most of all. ${ }^{57}$ In Rome, war declaration was a ritualistic endeavor carried out by "fetials," independent priests of Jupiter who served variously as diplomats, international law judges, and expert witnesses to the Roman Senate on the laws of war. ${ }^{58}$ Their primary charge, according to Plutarch, was to ensure that Rome did not enter an unjust war, and they had the power to prevent war's initiation where they saw it to be unmerited. ${ }^{59}$

50 See id. For a more general summary of intellectual influences on the framers' approach to foreign relations, see Saikrishna B. Prakash \& Michael D. Ramsey, The Executive Power over Foreign Affairs, 111 Yale L.J. 231 (2001).

51 See John Locke, Two Treatises on Government, Ch. XII (1690).

$52 \quad$ Id. at 327.

53 Baron de Montesquieu, The Spirit of Laws (1751).

54 William Blackstone, Commentaries on the LaWs of England (1765).

55 Mogens Herman Hansen, How Many Athenians Attended the Ecclesia?, 17 GreeK, Roman, \& Byzantine Stud. 115, 121 (1976).

56 Paul Halsall, Sparta, FordHAm UnIv., https://sourcebooks.fordham.edu/ancient/eb11sparta.asp, (last visited May 24, 2019).

57 Mogens Herman Hansen, The Tradition of the Athenian Democracy A.D. 1750-1990, 39 GREECE \& RoMe, 14, 18 (1992).

58 John Rich, The Fetiales and Roman International Relations, in Priests and STATE IN THE Roman World (James H. Richardson \& Federico Santangelo eds., Franz Steiner Verlag 2011). For a fuller discussion of the fetials and a deeper exploration of their role, see Alan Watson, International LaW in Archaic Rome: War and Religion (1993).

59 Id. at 190. 
The Constitution was not the first time that the Founders had vested powers over war and peace in the legislature. The Articles of Confederation established no executive branch and therefore vested the war power, by default, in the legislature, stating that "The United States, in Congress assembled, shall have the sole and exclusive right and power of determining on peace and war," ${ }^{60}$ allowing exceptions only for states' power to defend themselves against invasion by Indian tribes. ${ }^{61}$ Thus, when it came time to allocate war powers under the Constitution, institutional inertia would have been on the side of keeping that power in the legislature. Inertia, however, proved no safeguard against so many fundamental changes in the American system of government, so this alone was no guarantee. Rather, the framers' shared concerns about perverse incentives that might accompany executive war powers made legislative supremacy in war declaration uncontroversial.

Though the framers diverged over the desired strength of the new executive branch, they were in broad agreement as to what powers he should have with regard to war. George Mason, in characteristic distrust of executive power, opposed giving the executive war power, "because not safely to be trusted with it;... He was for clogging rather than facilitating war." ${ }^{2}$ By contrast, Founding Fathers such as Charles Pinckney, John Rutledge, and James Wilson all advocated for a singular executive but nonetheless shared Mason's apprehensions about vesting in that executive unilateral powers over warmaking decisions.$^{63}$ Alexander Hamilton proposed that the Senate have the "sole power of declaring war," leaving the president authority over "the direction of war when authorized or begun." 64

Broadly speaking, the Founders saw executive power over war as leading to the aggrandisement of that office and feared the perverse, glory-seeking incentives that it created, ${ }^{65}$ with Madison writing some years after the ratification that "the Ex. is the branch of power most interested in war, \& most prone to it. [The Constitution] has accordingly with studied care, vested the question of war in the Legisl." ${ }_{66}$ Hamilton, writing as Pacificus, took the contrary view that Congress was the more belligerent branch and that the executive would place a check upon such impulses, but he argued no less forcefully for the importance of separating powers on the issue and for the functional importance of requiring Congress to formally declare. ${ }^{67}$ Striking in this as in so many of the Founders' comments is that, contrary to the scholarly perspectives on war declaration both before and after them, the Founders did not see the question as being merely one of formality, tradition, fair warning to merchants or the enemy, or religious imperative but rather as a functionalist, political economy question about institutional incentives and the externalities

\footnotetext{
60 ARTICLES OF CONFEDERATION of 1781, art. IX.

61 ARTiCLES OF CONFEDERATION of 1781, art. VI.

62 Louis Fisher, Presidential War Powers 9 (3d. ed., 2013). Fisher's broader discussion of the history of war powers is invaluable, and this summary owes a great debt to his labors.

${ }_{63} I d$. at 4-5.

64 Id. at 5.

65 William Michael Traenor, Fame, the Founding, and the Power to Declare War, 82 CoRnell L. Rev 695 (1997).

66 Id. at 10.

67 See Alexander Hamilton, Letters of Pacificus No. 1 (1793) in The Pacificus-Helvidius Debates of 1793-1794: Toward the Completion of the American Founding at 8 , 11-16 ( Morton J. Frisch, ed. Liberty Fund, 2007).
} 
to the public of unchecked executive power to initiate war (albeit not in those anachronistic terms).

Overall, the Declare War Clause prompted no significant debate at the Constitutional Convention. The most notable exchange over it at the Convention was prompted by James Madison's and Elbridge Gerry's motion to substitute the word "declare" for what had thus far been called the power "to make war." ensuing debate evinces some confusion among delegates as to the significance of the change, but Madison's and Gerry's stated reason was to avoid any interpretation that might prevent the president from acting quickly to repel attacks before receiving a Congressional declaration of war. ${ }^{69}$ No real dispute emerged from these discussions, though, and the measure passed with ease.

In the end, war powers, broadly defined, extended well beyond the simple statement of Congress' power to declare war. The Commander-in-Chief Clause, in Article II, § 2, declared that "[t]he President shall be Commander in Chief of the Army and Navy of the United States, and of the Militia of the several States, when called into the actual Service of the United States," but the precise demarcation of what that role entails was left undefined, doing little to resolve these interbranch contests. Counterbalancing this role, seven clauses of the Constitution allocate war powers to Congress, including Clause 10 (defining and punishing piracies and felonies on the high seas, offenses against the Law of Nations), Clause 11 (declare war, grant letters of marque and reprisal, make rules concerning captures on land and water), Clause 12 and 13 (raise and support armies, maintain navy), and Clauses 14 through 16 (regulation of forces, call forth militia, discipline militia).

All of these Congressional powers read as preparatory or rule-making powers, constraining military action either by legal or fiscal means, fitting well with the idea of Congress setting the parameters for military action and leaving much of the prosecution of war to a more agile and decisive executive. This is not to say, however, that the framers took the commander-in-chief function to be any more immune from legislative oversight nor more likely to function well in the absence of such oversight than any other executive power; to the contrary, the aforementioned clauses together indicate a strong desire for legislative participation and oversight. And as the ensuing analysis and case studies will attest, the assumption that legislative oversight has a substantive effect on the satisfactory execution of policy is as reasonable in warmaking as in civilian matters. More controversially, I argue that Congress' proper exercise of the war powers granted to it has a substantive effect on legislators' attachment to war and their willingness to assert their oversight prerogatives beyond the initial declaration.

\section{THEORY}

\section{A. The INSTITUTION OF DECLARED WAR}

In the American political system, a declaration of war is a vote by elected representatives to commit publicly owned resources to the prosecution of a military

68 Michael S, Paulsen, The War Power, 33 Harv. J.L. \& Pub. Pol'y 113 (2010).

69 The Federalist No. 41, at 117 (James Madison) (Gideon ed., 2001). 
undertaking and to alter the existing constitutional and legal relationship between the people and government for the duration of the war in order to achieve a favorable outcome. ${ }^{70}$ As with any ordinary bill that is made into law by the federal government, it consists of a simple majority vote by both houses of Congress and the signature of the president. Should the president veto, the declaration is subject to the possibility of a legislative override of his veto by a two-thirds majority of both houses. By this process, a conditional exchange of powers and privileges is conducted between the state and the public that includes the provision for the suspension of habeas corpus under Article I, Section 8 of the U.S. Constitution and for the establishment of martial law. ${ }^{71}$ Economically, the expansion of government's power is total. In a time of war, the government may expand its claims to private industry's output through seizures, rationing, and/or price controls. ${ }^{72}$ In a passage shared by 20 th century declarations, they assert that "all the resources of the country are hereby pledged by the Congress of the United States." 73 In return for this expansion of its power, politicians commit, under threat of political punishment, to achieve a decisive and favorable outcome - be it defense of the homeland, conquest, or the elimination of threats abroad.

Unlike other acts of legislation, in which Congress makes law within the established constraints of the Constitution and delegates their enforcement to the executive, in declaring war, Congress arrogates to the federal government powers in excess of those normally granted by the Constitution in order to meet the needs of the country at that moment. Legislators conditionally grant the president, as commander-in-chief, managerial discretion over the conduct of the war subject to congressional oversight. The resulting arrangement can be thought of as a contract in which a mediator oversees a transfer of rights from one party in exchange for a guarantee of victory (however defined) from the other. The mediator (Congress) acts as trustee of those rights and monitors the recipient (the executive branch) to ensure that the terms are fulfilled to the best of its ability. The defining institutional trait of a declared war is the way in which it publicly and explicitly distributes political responsibility for the war between the executive and legislative branches. By accepting the responsibility of having authorized the war, legislators share with the executive in the costs and risks of failure (whether outright defeat or the failure to achieve certain stated goals) but also in a claim to credit should the United States prevail. The result is an alignment of costs and rewards that establishes a cooperative relationship between Congress and the executive with the fulfillment of commitments expressed in the declaration as their shared goal.

70 The commitment of publicly owned resources is invariably stated explicitly in American declarations of war, granting to the president the "entire naval and military forces of the United States and the resources of the Government"- that exact wording having been shared by all 20th century declarations but expressed in some variation in all American declarations. Official Declarations of War by Congress, United States Senate, , https:// www.senate.gov/artandhistory/history/common/generic/Origins_WarPowers.htm.

71 Provisions for martial law are likewise included in Art. I, $\S 9$ but have been further limited by subsequent pieces of legislation including the Posse Comitatus Act of 1878, 18 U.S.C. $\S 1385$ and the Insurrection Act of 1807, 10 U.S.C. $\S \S 331-335$.

72 Robert Higgs, Crisis and Leviathan: Critical Episodes in the Growth of American GovernMENT (2007).

73 Official Declarations of War by Congress, United States Senate, https://www.senate. gov/artandhistory/history/common/generic/Origins_WarPowers.htm. 
Though it is true that these powers are asserted and agreed upon by a simple majority, it is fair to say that the trustee role, as described, applies to a sufficient percentage of legislators to achieve substantial institutional commitment. Based on the fact that a majority of legislators in both houses are required to vote in favor of a declaration for it to pass and the assumption that voters' evaluation of legislators is dependent upon the legislators' individual voting records ${ }^{74}$, it seems safe to assume that a majority of legislators in both houses have, in the eyes of the electorate, some reputational attachment to the war being declared. The high margins by which declarations of war have historically passed indicates that the reputational connection to declared wars should be very strong. Thirteen out of seventeen votes to declare war in the House and Senate have done so with more than ninety percent of the vote, and in only one war (the War of 1812) has the United States declared with less than seventy percent support in both houses. Even if we reason that legislators who did not vote for a given declaration of war feel no obligation to involve themselves in the conduct of that war (a dubious proposition, given the rally-round-the-flag effect ${ }^{75}$ and historical efforts by dissenters, infra, to signal that despite their vote against a war they intend to be involved in its conduct), the passage of a declaration by majority vote assumes that unless and until a sufficient number of those legislators who supported the declaration are voted out, the reputational effect on legislators' attentiveness will prevail over a majority of both houses of Congress. It is arguable that this relationship could weaken if a declared war lasted so long that a considerable portion of congressional seats turned over before it was resolved, but as no declared war has reached the near-generational lengths of Vietnam and Afghanistan, such an eventuality is untested and arguably prevented by the very qualities that declarations are herein argued to possess. Thus, while it is reasonable to argue that the assumptions of responsibility described in this article do not apply equally to all legislators, it is likewise reasonable to presume that they apply to a sufficient portion of them to make these relationships function as described. All of this is to say that to the extent that voters derive utility and disutility from war, individual legislators' votes count.

Another worthwhile potential objection to this claim is that the declaration of war, which necessarily occurs at the outset of war, matters less than subsequent developments of the conflict and policy makers' positions on those developmentsbudgeting, adjustments of troop levels, revised depletion reports, diplomatic negotiations, etc. This objection is consistent with common observations as to voters' short memories. ${ }^{76}$ However, votes on whether or not to go to war are particularly conspicuous votes on a legislator's record and, anecdotally, have proven

74 Brandice Canes-Wrone et al., Out of Step, Out of Office: Electoral Accountability and House Members' Voting, 96 Am. Pol. ScI. Rev. 127 (2002); Stephen Ansolabehere et al., The Effects of Party and Preferences on Congressional Roll-Call Voting, 26 LeGIS. STUD. Q. 533 (2001).

75 John E. Mueller, Presidential Popularity from Truman to Johnson, 64 Am. J. Pol. ScI. 18 (1970).

76 See generally, Beth Miller, Failing to Recall: Examining the Effects of Trace Decay and Interference on Memory for Campaign Information, 34 PoL. Psychol. 289 (2013). Some evidence suggests, however, that voter memory can be influenced by favorable circumstances and effective politicking, see Michael M. Bechtel \& Jens Hainmueller, How Lasting Is Voter Gratitude? An Analysis of the Short- and Long-Term Electoral Returns to Beneficial Policy, 55 Am. J. Pol. Sci. 852 (2011). 
to "follow" politicians throughout their careers in a way that individual votes on troop levels or budgets do not appear to do. It seems fair to say that, given voter ignorance of day-to-day, "managerial" sorts of votes, a politician's vote on whether or not to go to war attaches him to the outcome of that war more than his votes on tedious technical matters of administration that quickly lose voters' interest. In war, voters derive utility from their country being victorious and secure with a minimum of casualties, economic costs, or infringement upon their rights and freedoms. Prowar and anti-war movements are popular fixtures in American history, whereas narrower pro-war-spending, anti-war-spending, pro-troop-increase, and anti-troopincrease activism is less common and, where present, generally a subset of pro-war or anti-war activism more generally.

The conceptualization of the declaration process as a model of contractual exchange allows us to apply a rational choice framework to the problem of war's initiation. Broadly speaking, we can describe the median voter's utility with respect to war as consisting of preferences for victory, variously defined, based on standards for success applied by voters; national security; personal political rights and freedoms that might be infringed upon by policy governing the conflict; casualties; and a variable capturing the aggregate, strictly defined economic costs of the war. This last can be thought to include both public and private spending on the war, the cost of wartime regulations, additional taxes, quotas, rationing, and, in rare cases such as the War of 1812, physical damage to property and infrastructure on the homeland. ${ }^{77}$ Utility from each of these is assumed to consist of both tangible as well as psychological benefits or costs, and each argument is assumed to affect both forms of utility in the same direction. Setting aside cases of voters who benefit or lose from war to a unique extent, we assume the effects of the war to be entirely public goods or bads.

A formal declaration of war provides for the maximization of voters' gains from military victory and, consequently perhaps, any resultant improvement in national security. A declared war will diminish voters' enjoyment of personal political rights though, as the following sections will address, perhaps no more than an undeclared conflict would. Casualties and material economic costs of war are ambiguously affected by the act of declaring. The history of American military engagements does not readily provide us with two conflicts, one declared and one undeclared, within a sufficiently narrow window of time and of comparable scale for us to adequately judge the effects of a declaration on political actors' tolerance for casualties and economic costs of war. There are logical arguments for seeing declarations as either increasing or decreasing said tolerance. On the one hand, it could be argued that once a declaration is approved, the enhanced incentive to achieve victory would lead elected officials, ceteris paribus, to be more willing to spend lives and wealth to achieve victory. On the other, in the absence of a declaration, legislators are not as vulnerable to voter dissatisfaction with a conflict's adverse effects and may be less responsive to a protracted war with severe economic costs and heavy casualties.

This ambiguity requires me to limit my argument to the claim that declarations increase the probability of victory in war without claiming a clear positive or

7 Each of these variables will be subject to public perception and interpretation, and no assumption is made here that public opinion is perfectly reflective of objective realities nor that public opinion on a given war is or is not affected by biases - random or systematic. 
negative effect on the costs to the voter. The argument for declarations thus cannot be based on a claim of pure cost-reduction but rather of benefit-maximization. In terms of the model, declarations are seen to maximize politicians' incentives to provide victory and national security, though not necessarily to reduce casualties or economic costs. Formally declaring thus in no way supplants or affects the need for diligence in fiscal management of the conflict nor strategic leadership to achieve objectives with a minimum of casualties, though the following analysis of elected officials' utility with respect to war certainly allows for the possibility that greater political accountability could affect fiscal cost-reduction and the lessening of casualties. Geys finds the fiscal costs of war to have had a significant effect on presidential approval ratings in Korea, Vietnam, and Afghanistan/Iraq, though his results for the effect of casualties on said approval are insignificant once fiscal costs and casualties are both included in his regression..$^{78} \mathrm{~A}$ significant literature, however, does find significant adverse effects of war casualties or the logarithm of war casualties on presidential approval. ${ }^{79}$ Feaver and Gelpi, though not controlling for non-military political or economic events, contrastingly find a positive relationship between war casualties and presidential approval when the military intervention in question is considered successful. ${ }^{80}$ Whatever the direction of the effects, the wealth of the evidence suggests that both economic costs and casualties influence political opinion with regard to war.

The utility of politicians is similarly ripe to be dissected, though key to my analysis here is the assumption that the costs and benefits of war to politicians in the legislative and executive branch are not one in the same. Politicians are assumed to seek re-election by maximizing the median voter's satisfaction. ${ }^{81}$ With respect to war politics, we contend they do so by either maximizing voters' utility from war or, as war is a venture shared between the executive and legislative branches, by altering perceptions of accountability for the status of the war-claiming credit for themselves in increasing war's benefits and minimizing its costs while blaming the other branch for any reductions in benefits and increases in costs. Thus, politicians' utility from the war is a function of both voters' utility from war and the ability to reallocate credit and blame in voters' eyes.

Certain assumptions apply. Politicians in both branches are assumed to be risk averse. For politicians in each branch, blame leveled against them reduces their utility from war, whereas the alternate branch's blame is assumed to enter positively, offsetting it. ${ }^{82}$ Politicians of each branch are assumed to be jealously

78 Benny Geys, Wars, Presidents, and Popularity: The Political Cost(s) of War ReExamined, 74 Pub. Opinion. Q. 357 (2010).

79 John E. Mueller, War, Presidents, and Public Opinion (1973); Samuel Kernell, Explaining Presidential Popularity. How Ad Hoc Theorizing, Misplaced Emphasis, and Insufficient Care in Measuring One's Variables Refuted Common Sense and Led Conventional Wisdom Down the Path of Anomalies, 72 Am. Pol. Scr. Rev. 506 (1978); Robert S. Erickson et Al., The Macro Polity 57-60 (2000).

80 Anthony Downs, An Economic Theory of Democracy (1957); Duncan Black, On the Rationale of Group Decision-Making, 56 J. PoL. Econ. 23 (1948).

81 A nascent but intriguing literature has emerged in recent years on the economics of blame. Mehmet Y. Gurdal et al., Why Blame?, 121 J. Pol. Econ. 1205 (2013).

82 Christian R. Grose \& Keesha M. Middlemass, Listen to What I Say, Not How I Vote: Congressional Support for the President in Washington and at Home, 91 Soc. ScI. Q. 143 (2010). 
protective of their own measure of accountability and it is assumed that the selfinterested motives of politicians dominate any effects of partisan loyalty shared by the executive and members of the president's party in the legislature. ${ }^{83}$ This examines blame in an experimental setting, concluding that "Blame may not be justified on the basis of what can be observed or inferred, but the common knowledge that it exists makes it a powerful incentive - a contract — and assures that, more generally, it will be justifiable: agents will have incentive to employ effort toward the mental and physical activities needed to benefit the principal, whether or not the principal understands or observes these activities. By doing so, blame implements a characteristic and counterintuitive property of the optimal contract in the principal-agent model: that the payment is dependent on events that are outside the control of the agent and, in some cases, events that do not influence the principal's payoffs." ${ }^{84}$ Charles Tilly, in The Blame Game (2010), ${ }^{85}$ writes of the economic and sociological use of blame in political debate, with particular reference to its use in the War on Terror:

Credit and blame are no mere game. In American public life and across life in general, who gets credit and blame matters. It matters retroactively and prospectively. It matters retroactively because it becomes part of the stories we tell about good and bad people... It matters prospectively because it indicates whom we can trust, and whom we should mistrust. Day after day, people spend plenty of effort assigning credit and blame. They take it seriously. So should we. This is not to argue that no such camaraderie exists; merely that, on the margin, politicians choose their own well being over that of fellow party members in the other branch. Where credit is concerned, politicians of each branch are assumed to only be directly concerned with their own credit (blame) for positive (negative) developments or their own share of overall credit (blame) but, partisan considerations aside, are not assumed to begrudge the other branch any positive surplus in public opinion. ${ }^{86}$

This similarly raises the question of why credit and blame are traded primarily between branches rather than primarily between individual politicians. This is, in large part, a historical, empirical observation. The case studies that follow display numerous instances of - even in declared wars - attempts by one branch to ascribe ownership of the war to the other branch. Given the managerial role of the executive in military conflicts, this almost always manifests as the legislature attempting to shift full responsibility for a war's initiation and outcome to the president via such monikers as "Mr. Madison's War," "Mr. Polk’s War," etc. We theorize that the struggle over credit and blame between branches is cost-minimizing from the standpoint of legislators trying to gain the favor of rationally ignorant voters. Feuding words and debates between legislators or between a president and senator

83 Glenn R. Parker, Some Themes in Congressional Unpopularity, 21 Am. J. PoL. ScI. 93 (1977).

$84 \quad I d$.

85 Charles Tilly, The Blame Game, 41 Am. Sociologist 382 (2010).

86 Id. 
are likely to be more tiresome to voters than, say, Democrats' invocation of slogans such as "Bush Lied, People Died" during the Iraq war. Inter-branch blame is a less costly way for incumbents to secure their own reputations than attempting to relay the who-said-what of legislative debate to low-to-moderate-information voters.

Furthermore, neither credit nor blame in the public eye are perfectly traded between politicians of the two branches at a 1:1 ratio. That they can be shared in some proportion by politicians of both branches establishes a loose relationship in the interbranch exchange of accountability. Positive developments in the war can theoretically lead to any distribution of credit between executive and legislative branch politicians, just as negative developments can theoretically lead to any distribution of blame between them. This is supported empirically by Parker, ${ }^{85}$ who finds that "presidential popularity seems to have no noticeable effect on Congressional unpopularity" once relevant controls have been applied. In response to a fall in the median voter's net benefits from war, the legislature is thus capable of stoking blame against the executive to such an extent that it can perfectly shirk, with all blame falling on the executive but no positive benefits to legislators. Perfect shirking, however, is not an upper bound. It is entirely conceivable that in response to a fall in voters' net benefits from war, an increased flurry of blame leveled against the executive could be great enough as to yield legislators political gains in response to voter dissatisfaction. The argument for declarations is not that they ensure a perfectly equitable 50-50 distribution of credit or blame between politicians of the two branches. It is that in the determination of legislators' utility from war, the propensity for blame to be shifted to the executive is at least constrained such that legislators are not immune from all accountability for the war and cannot use negative developments in the war advantageously for their own electoral benefits. Legislators are less able to maintain immunity from voter dissatisfaction with the war or to opportunistically achieve political gains by stoking dissatisfaction with the executive.

Also worth addressing is the reverse of our concern here: that a declaration which involves Congress more deeply in the prosecution of a war risks legislative meddling that might complicate its management with the usual vicissitudes of micromanagement and demagoguery, leading to less favorable outcomes. The text of the Constitution suggests that the Founders feared this. Waging war is one of the executive's inherent powers and was vested in the monarch in every state that the Founders would have known in their lifetimes and in nearly every historical case of which they were students (with the noted exceptions in periods of Ancient Greece and Rome). The power to declare it is a partial divestment. The reason why the Commander-in-Chief Clause appears is to clarify that whereas Congress has the power to declare war, the president has the power to manage it. It is worth asking, then, whether there is a means of credible legislative commitment not to meddle. As the foregoing analysis might suggest, though, the risks here are rather single-tailed. The natural inclination of many legislators from the early years of the republic has been to try to shift full responsibility for war-making onto the executive and enjoy the quieter life of peacetime domestic policy. From a public interest standpoint, then, the required institutional solution is not a "corridor" system that would limit deviations in legislative behavior in either direction but a "floor" system that simply limits the downside risk of shirking. In other words: a commitment device.

Lastly, the effectiveness of declarations of war in altering voter perceptions of credit and blame for politicians of either branch hinge upon public awareness of the declaration. It is reasonable to assume that even a poorly-to-moderately informed voter will know whether the United States is engaged in any major armed conflict at 
a given time, but if a notable percentage of the general public is unaware of whether Congress has formally declared war or whether a given conflict is an executive-led undertaking, then the role of the declaration in allocating credit and blame-and therefore in enhancing commitment-would be significantly diminished. As we turn to case studies in the next section, it will be necessary to establish whether the general public was reasonably aware of Congress's participation in the act of declaring war for us to say confidently that the declaration played a role in enhancing legislative commitment. In general, however, two claims can be made in favor of my argument. First, declarations are open acts of Congress that are as susceptible to public scrutiny and analysis as any other legislation and are very widely publicized when they do occur, such that there is no strong basis for believing that any voter with an interest in knowing whether war has been declared should face considerable costs in obtaining that information. Second, until the Korean War began in 1950, the United States had never engaged in a large-scale military conflict against a foreign power without a formal declaration. ${ }^{87}$ Thus, unlike the current era, to American voters of the past there were not multiple ways in which major wars were fought; they were formally and very publicly declared, as will be discussed in the coming sections. Given the clear language of the Constitution empowering Congress alone to declare war, until that practice was abandoned it was simply the way of going to war. Nonetheless, we will address the issue of voter ignorance in the case studies.

This analysis leaves us with some important assertions and limitations. The assertions are that declarations of war enlist legislators as monitors over the political conduct of war and that the desire to take credit for a war's positive developments and avoid blame for negative developments lead those legislators to effectively improve the outcome of a war through better oversight. The legislators' ability to shift blame for unfavorable developments in the war is bounded by their having given written approval for the war, delegated extraordinary powers to the executive, committed all of the resources of the country to themselves, and assumed the roles of monitors over the war's prosecution. Though it could be argued that even in the presence of a declaration, legislators could still blame the executive's management of the war, history indicates that, having passed a declaration, legislators are seemingly more active participants in that management through their oversight powers and that they treat the war more as they do Congressionally passed law or Congressionally administered regulation than like the workings of executive bureaucracy. The result is an improvement of the median voter's welfare with respect to war by making victory more probable and, where observed, more complete.

The limitations of this theory are (i.) that a case cannot be made that declarations unambiguously reduce the costs of war, only that they improve the probability of a successful outcome and whatever spoils may result; and (ii.) that the declaration

87 I admittedly make some exceptions in saying "against a foreign power," but I believe it to be justified. The American Civil War was obviously a notable instance of internal conflict that did not receive a formal declaration but in which the U.S. was victorious. However, with internal conflicts the choice to formally declare confers a measure of diplomatic formality to an internal rebel group that would contradict the federal government's claim that such groups are illegitimate. Thus, the logic changes. I also do not see intranational conflicts as suffering from the sort of political commitment problems that international ones can, since loss in a civil conflict usually spells much greater personal and political risks, so I make no claims one way or the other as to declarations in such instances. 
carries no promise of a perfectly equitable distribution of credit and blame between the two branches, only one in which blame cannot be so drastically shifted onto the executive that legislators are unaffected or positively affected by the costs of war placed on voters. Thus, from the standpoint of maximizing the median voter's utility from war, the case for declarations is that legislators, having explicitly signed on to a role in the war's initiation, are thereby more directly accountable for its prosecution and restricted in their ability to shift credit and blame at their convenience. The relationship between voter utility and support for incumbent legislators is thereby strengthened insofar as voters base their votes on utility from the war, and legislators, in order to maintain support, must expend greater effort towards increasing voter utility and less towards manipulating public perceptions.

\section{B. UNDECLARED ConfliCtS as InSTITUTIONAL FAILURE}

An undeclared conflict under the American model of government is a decidedly executive undertaking. In some cases it has entailed an authorization by Congress that grants approval for military engagement under unspecified Congressional oversight to be conducted (or not) at legislators' discretion. More often, it has consisted of unilateral executive discretion over the choice to engage, the scale of forces to be employed in the task, the objectives to be achieved, and the time and manner of withdrawal. In some cases this practice may be the result of divergent views by the executive and legislators as to whether to engage in war, with the executive proceeding against the will of Congress. More often, it is the result of a shared preference by politicians in both branches for less restrained executive action. In any case, it is a failure of monitoring such that the institutional structure designed by the framers breaks down and costs and benefits become misaligned, diminishing political commitment to those guarantees given by government to the public.

In an undeclared conflict, there is no change in the fundamental legal and constitutional relationships between the people and their government. No explicit grants are given to Congress committing the nation's resources to the prosecution of the conflict and no legislative procedure is mandated. Prior to the 1973 War Powers Resolution ${ }^{88}$, the accumulated war powers of the executive had grown such that no vote was required that would involve Congress in the decision of whether to engage in a foreign conflict. Since 1973, the president has only been required to report upon the hostilities and consult with Congress on an ex post basis within sixty to ninety days of engagement. Even this provision, despite being included in Congressional authorizations, has gone largely unenforced. As one monograph on the subject observes, "Every president since Nixon, Democrat and Republican, has refused to recognize [the Resolution's] constitutionality... Only once, for Lebanon in 1983, has the War Powers clock even been started, and then the president was granted an eighteen-month grace period. And when launching smaller-scale military operations, presidents frequently have dodged the resolution's reporting requirements. Rather than correcting for gross imbalances in the nation's system of separated powers, the War Powers Resolution, astonishingly, turned bad to worse." ${ }^{89}$

\footnotetext{
88 War Powers Resolution, 50 U.S.C. $\S$ 1541-48 (2019).

89 William G. Howell \& Jon C. Pevehouse, While Dangers Gather: Congressional Checks on Presidential War Powers 4 (2007).
} 
Larger engagements conducted within the framework established by the Resolution have received Congressional approval via Authorizations for the Use of Military Force (AUMF's), whether before the president orders military action or after the fact. Though issued by a majority vote of Congress, AUMF's do not constitute the same transformation of legal and constitutional relationships as a formal declaration. As a Congressional Research Service analysis of the differences notes,

With respect to domestic law, a declaration of war automatically triggers many standby statutory authorities conferring special powers on the President with respect to the military, foreign trade, transportation, communications, manufacturing, alien enemies, etc. In contrast, no standby authorities appear to be triggered automatically by an authorization for the use of force, although the executive branch has argued, with varying success, that the authorization to use force in response to the terrorist attacks of 2001 provided a statutory exception to certain statutory prohibitions. ${ }^{90}$

These standby authorities allowed for by a declaration number at approximately $250 .{ }^{91}$

In issuing AUMFs, however, Congress has frequently refused to explicitly name a country or entity against which the executive shall use military force, instead providing a general cause such as responding to the September 11, 2001, attacks and leaving it to the president's discretion how far the war should be carried and across which political boundaries. Thus, under an AUMF, Congress is giving the president considerably greater diplomatic leeway and unilateral discretion over decisions to militarily engage the governments or inhabitants of other countries so long as the executive justifies those engagements as being in the service of a broad public purpose or agenda stated by the AUMF. ${ }^{92}$ As Paulsen has written,

Congress, in enacting the AUMF, sweepingly and in separation of powers terms somewhat surprisingly declared its acceptance

90 Jennifer K. Elsea \& Matthew C. Weed, Cong. Research Serv., RL31133, Declarations

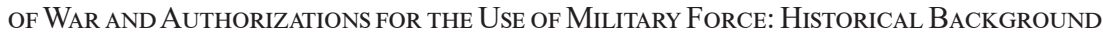
AND Legal Implications (2014).

91 Id.

92 An arguably parallel process occurs when the president uses political commitments such as the 2015 Joint Comprehensive Plan of Action as a substitute for treaties when he cannot get the support of a majority of the Senate. Softer promises stand as substitutes for the sanctity of law. It is not clear whether or how a set of incentive effects arises comparable to what is described here, but it is an interesting question to be explored. In principle, it seems logical to assume that the same diminished legislative attachment to the terms of the commitment should result, but unlike the legislative consent afforded when Congress grants an AUMF, resort to a political commitment, as in the $2015 \mathrm{JCPOA}$ case, seems more of an executive last resort that is limited by Congress' refusal to give it statutory force. The president is then left to act within his constitutional parameters as chief diplomat. In any case, Congress has not shown itself willing to fully abandon its rights in treaty-making as it has in war-making, so the question remains hypothetical. 
of unilateral presidential military action... and the claim of unilateral presidential constitutional authority to do so... All of this is extraordinary. The AUMF marks a stunning, landmark paradigm shift in the constitutional practice of war powers, light years distant in tone and attitude from the War Powers Resolution of $1973,,^{93}$

which, as noted, was a departure from the traditional, constitutional model in itself. In short, in an undeclared conflict, if legislators have participated at all, it has been to authorize the executive to undertake military action without mandating a relationship of accountability or an oversight role for themselves.

The framework that this establishes is best described by Sidak, who distinguishes between a "Coasean trespass" between branches of government, in which one branch assumes powers constitutionally granted to another without the other's consent, and "Coasean bargains" in which two parties implicitly agree to transfer constitutional powers between them, thereby pursuing their own preferences at the expense of the electorate. ${ }^{94}$ In the Coasean bargain, both branches rely upon the other's consent not to bring unwanted attention to this exchange, and with no party seeking judicial review of the practice it is left to private parties to enforce compliance with the Constitution. ${ }^{95}$ With sovereign immunity in effect, monitoring costs of government high, and the costs of such constitutional indiscretions dispersed, the incentive to force adherence to the Constitution's allocation of powers is low for any given actor. This invites the proposal of a sort of "Inverse Coase Theorem" in which, from the electorate's standpoint, "monitoring costs [would be] reduced, and political accountability enhanced, by prohibiting bargains that alter the Constitution's formal allocation of rights of decision among political actors" but in which the political will or ability to do so is lacking. ${ }^{96}$

Given the paucity of efforts by Congress to reassert its own constitutional authority in warmaking, the current arrangement appears to be a clear-cut Coasean bargain in which legislators have exchanged their constitutional powers for electoral stability and the executive has accepted this transfer in exchange for a greater share of credit for American victory and security. As a result of this bargain, from the standpoint of the electorate, an executive military action is troubled by an implicit collusion between its would-be agents in Congress and the executive branch.

The value of the declaration to the public, as asserted in the previous section, was that it bound legislators to a formally established role in the war-making process. With legislators unbound from their roles as mediators and trustees, the executive branch is permitted to proceed, less constrained, in the engagement of military forces. Risk-averse legislators are better able to avoid oversight of or involvement in the conflict and continue to govern as they previously had with minimal added political risks and responsibilities of wartime. Meanwhile, in the absence of Congressional oversight, the expenditures of lives and wealth on a conflict are choice variables for the executive branch politicians that they can increase without checks on their

\footnotetext{
Michael S. Paulsen, The War Power, 33 Harv. J.L. \& Pub. Pol'y 113 (2010).

J. Gregory Sidak, To Declare War, 41 Duke L.J. 27, 64-65 (1991).

Id. at 65.

96 J. Gregory Sidak, The Inverse Coase Theorem and Declarations of War, J. 41 DukE L.J. $325,326(1991)$.
} 
discretion in order to achieve victory and a greater degree of national security for which they can take credit. As Gene Healy has written,

Individual presidents have every reason to protect and expand their power but individual senators and representatives lack similar incentive to defend Congress's constitutional prerogatives. 'Congress' is an abstraction. Congressmen are not, and their most basic interest is getting reelected. Ceding power can be a means toward that end: it allows members to have their cake and eat it too. They can let the president launch a war, reserving the right to criticize him if things go badly. ${ }^{97}$

Empirically, there is evidence of this decline in monitoring. Fowler, in an extensive study of Congressional oversight of U.S. foreign policy, "concluded that key Senate committees with responsibility for oversight of the executive showed an unprecedented lack of monitoring during a major conflict and a failure to establish accountability after hostilities ceased" in conflicts since the end of World War Two. ${ }^{98}$ There is likewise evidence in historical approval ratings for the claim of Congress's immunity from the effects of war. Parker, looking at the period of 1939 to 1974, finds no statistically significant relationship between Congressional approval ratings and war: "The lack of a substantial relationship between the existence of war and the unpopularity of Congress would seem to suggest that Congress, unlike the presidents in Mueller's analysis, is not held responsible for our involvement in foreign wars. The president's position as Commander-in-Chief, his preeminence in the area of international affairs, and the historic participation of presidents in the conduct of wars may overshadow Congress' constitutionally prescribed power to declare war." ${ }^{\text {999 }}$ Granted, the sample years that Parker uses include the years of World War II, and the data are unfortunately not cleanly severable, so a counter-argument could be made that the relationship between Congressional approval and wartime was not significant there either, but as he notes, Mueller's analysis of the effects of casualties on presidential approval ratings in particular suggests some differential effect in the cases of Korea and Vietnam. ${ }^{100}$ Reinforcing this, Parker finds that the existence of international crises is positively correlated with Congressional approval ratings, making it doubtful, were we able to measure the effects of individual wars, that they would be a net cost to legislators in this period. ${ }^{101}$ Berinsky, looking at World War II and the Iraq War, translates Zaller's well known elites theory ${ }^{102}$ into wartime politics, finding that when political elites are in agreement on the merits of military action, voters give them considerable leeway in the war's political conduct and administration; when elites are divided, voters follow their respective party

97 Gene Healy, Congress: The Least Dangerous Branch, Cато Ат LiberTy (Apr. 12, 8:59 AM) https://www.cato.org/blog/congress-least-dangerous-branch.

98 Linda L. Fowler, Watchdogs on the Hill: The Decline of Congressional Oversight of U.S. Foreign Policy xiii (2015).

99 Glenn R. Parker, Some Themes in Congressional Unpopularity, 21 Aм. J. Pol. Scr. 93, 104 (1977).

100 John E. Mueller, War, Presidents, And Public Opinion 226-31 (1973).

101 Parker, supra note 99, at 108.

102 John R. Zaller, The Nature and Origins of Mass Opinion (1992). 
leaders. ${ }^{103}$ It does not appear to be a great logical leap to infer from these findings that if legislators are not adversely affected by war in the post-World-War-Two era and might stand to gain from it (a la Parker) but presidents remain susceptible to the war's developments ( $a$ la Mueller), then an institutional commitment device that better attaches a wider swath of American politicians to the initiation of the war might prevent the polarization effect from dominating to such an extent that legislators could gain from voters experiencing diminished utility from war.

In the terminology of my earlier analysis, the effect of foregoing the commitment device can be conceived of as diminishing both the credit and blame allotted to legislators, neither improving nor diminishing legislators' reputation with voters but rather satisfying legislators' risk aversion by insulating them from changes in the median voters' utility from the conflict. If the casualties and economic costs of war grow such that voters' net returns from war turn negative, legislators, having assumed either no monitoring role for themselves or a notably diminished one, are free to place greater blame on the executive until their own well being is fully restored or even increased beyond its previous level. The possibility for legislators to achieve political gains by placing greater blame on executive branch politicians suggests that in addition to insulating themselves from the political risks of war, legislators may well benefit from the median voter's loss of utility from the conflict. In practice, whether legislators shift blame onto the executive merely insofar as to insulate themselves from voter dissatisfaction or choose to opportunistically gain from the voter's loss is a function of broader political considerations such as whether the president's party has a legislative majority, the strength of the president's party in cultivating consensus and limiting defection, the vulnerability of legislators' states and districts, etc.

In a representative government, the proposition that a collusive bargain could transpire between politicians of these two branches in which elected politicians are able to reallocate power between them per their own preferences, irrespective of an established constitution, suggests a lack of completeness in the assignment of powers. That politicians might, as a result of that incompleteness, transform a loss of voter utility into a gain for themselves suggests an institutional failure and an inversion of the principal-agent model on which the United States Constitution was explicitly based. The resulting costs that have been incurred by the United States throughout a long series of undeclared conflicts thus signal not only the risks of military engagement without declarations but, more fundamentally, the potential for perverse incentives and the reallocation of constitutional powers wherever negotiation between branches is not prohibited and is costly to monitor.

The ultimate consequence of such institutional failure in the context of military policy is a significantly diminished legislative commitment to achieving decisive and favorable resolutions to foreign conflicts. Legislators, having never attached their reputations to an engagement, are insulated from its political costs and, in the extreme, stand to potentially gain from a fall in the median voter's utility from war. This diminishes legislators' incentive to apply the weight of their collective offices to oversight of the executive's conduct and nullifies the benefit of divided government and the system of checks and balances that was designed as the

103 Adam J. Berinsky, Assuming the Costs of War: Events, Elites, and American Support for Military Conflict, 69 J. PoL. 975 (2007). 
linchpin of the American system of government. From the executive's standpoint, the political cost of engagement is lower and the potential for undivided credit is increased, thereby increasing the propensity for more frequent military activities that are more costly to the electorate relative to the benefits that they are meant to attain. The more costly and politically unpopular the conflict, the less legislative participation can be expected, leaving the longest, most challenging military ventures to see diminishing political pressure for the achievement of stated U.S. objectives. Based on this view of undeclared conflicts, the predicted result is a pattern of frequent and inconclusive engagements in which legislative involvement in and oversight of military policy is significantly reduced relative to declared wars.

\section{CASE Studies}

A theory of declared and undeclared wars at our disposal, the remaining challenge is thus to look at those cases in which the United States has formally declared war as well as those in which it has militarily engaged without a declaration in order to determine whether its behavior is consistent with this theory's predictions. The predictions are (i.) that instances in which a war is formally declared will see greater legislative oversight over its prosecution than instances in which it is undeclared and (ii.) that declared wars will be pursued to more decisive and favorable ends than undeclared conflicts. I will make a general argument in each case for both points and will substantiate the second point with other parties' interpretations of victory, such as Feaver and Gelpi ${ }^{104}$ and the Correlates of War Project ${ }^{105}$, which covers conflicts from 1816 to 2007.

One criticism that the foregoing theory readily invites is that of selection bias: might legislators be more likely to declare war in those instances in which they believe beforehand that the United States is likely to succeed? According to this line of reasoning, legislators consent to formally declare war because they recognize from the outset that the United States is highly likely to emerge successful, thereby minimizing the political risk of their decision. Conversely, they avoid formal declarations when they perceive the United States to be in a more tenuous position and prefer not to attach themselves to what they foresee to be a riskier venture. This criticism offers clear-cut predictions: when it can reasonably be said that the United States is in a more advantageous position relative to an adversary at the outset of a conflict, Congress will be more likely to declare war; among that pool of conflicts in which the United States and its opponent are more evenly matched or in which the United States is seen as being at a disadvantage, however, undeclared wars will be more common. Another worthwhile critique is that of rational ignorance. It can be argued that declarations are an inadequate explanatory variable because voters are unaware that war has been formally declared. Historical evidence on this is difficult to find, making the critique hard to conclusively refute, but I will present arguments as to why it is unlikely to be an undermining factor.

Thus, for the theory to be seen as descriptive, both predictions must be borne out, the selection bias critique must be refuted, and it must be shown that voters are

104 Peter D. Feaver \& Christopher Gelpi, Choosing Your Battles: American CivilMilitary Relations and the Use of Force (2004).

105 Meredith Reid Sarkees \& Frank Wayman, Resort to War: 1816-2007 (2010). 
sufficiently aware of the declaration of war for the accountability relationships to function as described by the model. That is what the following case studies will examine.

\section{A. DECLARED WARS}

\section{i. The American Revolution}

The United States began, in a sense, with a declaration of war. The Declaration of Independence was surely more than that - a statement of diplomatic intent, an assertion of rights, and an impassioned statement on moral and political philosophybut among its core political functions was to formally declare the American colonies' willingness to defend their intentions to separate by the use of military force, or what they could muster of it. The Declaration is frequently treated as a mere statement of grievances or a spirited profession of intent by the Second Continental Congress, but as Sandefur ${ }^{106}$ notes, no other issuance by the Congress is held in such a token manner. All other acts by that body have been retrospectively viewed as carrying the full legal weight of the colonial governments, and the exception made in the case of the Declaration is not so much logically argued as arbitrarily assumed. Thus, attributing to it the same legal status as the Congress's other issuances, the Declaration of Independence can be viewed as, among other things, a declaration of war, complete with an even greater position of accountability for the legislature, as there was at that time no executive to oversee its prosecution. The Continental Army and Navy thus reported and received direction from the legislature itself.

Of the innumerable historical accounts since written of the Founders and the American Revolution, no notable claim or debate has emerged to the effect that the Second Continental Congress was not attentive and involved in its leadership of the war. This is understandable given the circumstances. Aside from being America's first war as an independent country, the Revolution was unique in the stakes that it imposed on political actors, with every signer of the Declaration reasonably sure that he would personally face execution and his family be divested of their property should the effort fail. Thus, the Revolution can be viewed as an extreme case of the greatest personal stakes faced by political actors who elected to declare war. Their level of involvement in the war's prosecution both as a body and individually bears out the predictions of this model. Two and a half weeks after the Declaration's signing, they had established a Board of War to oversee the administration of the war, and though none of the signers would be killed in battle, one third of them served as militia officers during the war, four were taken captive, and many lost considerable personal wealth in the process.

Historian Gordon Wood writes:

In 1763, Great Britain straddled the world with the greatest and richest empire since the fall of Rome. From India to the Mississippi River its armies and navies had been victorious. The Peace of Paris that concluded the Seven Years' War... gave Britain undisputed dominance over the eastern half of North America. ${ }^{107}$

106 Timothy Sandefur, The Conscience of the Constitution 14-15 (2014).

107 Gordon Wood, The American Revolution 4-5 (2003). 
Its resources beyond North America were likewise impressive and mobile, capable of being directed to a different corner of the empire should dissent turn to insurrection, as it gradually did in the 1770's. Britain quickly responded to unrest in the American colonies with an escalation of troop levels and punitive political measures. At the time of the signing of the Declaration of Independence in 1776, as Wood writes, "a military struggle seemed to promise all the advantage to Great Britain. Britain was the most powerful nation in the world... the British navy was the largest in the world, with initially half its ships committed to the American struggle." The Americans, by contrast, "had to start from scratch. The Continental Army they created numbered usually less than 5,000 troops, supplemented by state militia units of varying sizes. In most cases inexperienced amateur officers served as the American military leaders." 108

Granted: Wood is quick to note that in some senses this great discrepancy was misleading, with significant disadvantages for the British including three thousand miles of ocean separating them from the front lines of the war, complete with the communications, logistical, and supply problems that it imposed. He likewise cites the size of the American territory, the wild terrain, and the colonies' cultural and political fragmentation as obstacles for the British Army. Wood, however, may be in some ways giving the British too much of a handicap. The obstacle of the Atlantic was not small, but oceans had not prevented Britain from establishing lucrative trade lines around the globe, holding colonies in America for over a century, establishing by force other powerful footholds to its empire in India and the Far East, nor making war when necessary to protect them. As for the size of the American territory, the terrain, and social fragmentation, these can be seen as being equally an obstacle to both combatants. It is arguable that such features, especially the social characteristics, were often as troublesome for the revolutionaries as for the British.

Whatever the developments that would come throughout the war- the escalation of British forces in North America to over 50,000, with 30,000 German mercenaries supporting them; the foundation and development of the Continental Army and Navy; and a long series of bloody battles - it seems reasonable to say that the Continental Congress could not confidently have perceived war with Great Britain to be easily undertaken or decidedly winnable. Thus, the selection bias critique is weak in this case. As much can be deduced from Founders' writings in that era. George Washington wrote in his general orders in January of 1871, "We began a Contest for Liberty and Independence ill provided with the means for war-relying on our own Patriotism to supply the deficiency." 109 And Benjamin Rush would write in later years to John Adams on the dim mood of the Declaration's signing, "Do you recollect the pensive and awful silence which pervaded the house when we were called up, one after another, to the table of the President of Congress to subscribe what was believed by many at that time to be our own death warrants?" 110

As to the public's knowledge of a formal declaration, I grant that the Declaration of Independence was presented as a conditional ultimatum, but it did make clear that if King George III did not peaceably accept the secession of the colonies from

08 Id. at 76.

109 Senagan P. Sculley, Contest for Liberty: Military Leadership in the Continental Army, 1775-1783 397 (2019).

110 Benjamin Rush, To John Adams from Benjamin Rush, National Archives, (July 20, 1811), http://founders.archives.gov/documents/Adams/99-02-02-5659. 
the British Empire then the Americans were willing to resort to force. Given that anti-British sentiments had been manifesting in armed skirmishes for over a year, there was little expectation that the British would allow the colonies' departure without a fight. As for awareness of the Declaration itself, news spread rapidly, with descriptions of the Declaration or, just as often, its full text printed on the front page of major newspapers in the colonies' larger cities. Public readings were common, and whether in print or public profession the Declaration was widely publicized across the English-speaking world and Western Europe by the summer's end. ${ }^{111}$

The American Revolution, on these observations, appears to vindicate this model. Though the governing structure was different than in our other case studies, lacking an executive branch, it is entirely possible that members of the Second Continental Congress, or some portion of them, could have shirked, distanced themselves from the war's administration, or individually abandoned the effort had they not literally signed their names to it from the outset. Histories of revolutions often demonstrate the ability of elites to lessen their involvement when the costs of participation rise. If we wish to understand why not one of the fifty-six signers defected nor abdicated his role in the Revolution, in addition to their own moral convictions we can read the effective commitment achieved by a formal document to which each man signed his name and attached his reputation. The American Revolution enjoyed an overwhelming support from its political leaders, was seen through to a decisive and favorable end, cannot be said to suffer from selection bias in the sense of legislators declaring because they felt exceedingly confident in their success from the outset, and, given its public readings and rapid publication at home and abroad in multiple languages, it is difficult to imagine that any notable percentage of the population was not quickly aware of the Declaration's signing and the new state of war. America's first experience with war, despite the institutional differences with its post-Constitutional governing structure, thus serves as one of the best examples of the effectiveness of a signed declaration fostering unified political stewardship over the prosecution of war.

\section{ii. The War of 1812}

The vote to declare war against Great Britain again in 1812 is, to date, the narrowest vote for war in the history of the United States. It proceeded with only fifty-nine percent support from the House of Representatives and sixty-two percent from the Senate. ${ }^{12}$ Reticence to engage in the war stemmed primarily from the belief that the United States was grossly uprepared for the scale of conflict that would be required and secondarily from belief that the escalating problems with Great Britain could be reconciled by peaceable, diplomatic means. Among the examples provided by American history, it thus offers the best opportunity to examine whether the argued effect of a formal declaration is weakened or fails when the margins by which it is passed are small and when confidence in achieving a favorable outcome is lacking.

111 Jared Keller, How the Declaration of Independence Went Viral: a Brief Media Chronology of America's First Big Story, in PAC. STANDARD, (June 28, 2016), https://psmag.com/ how-the- declaration-of-independence-went-viral954127bb6e31\#.ofmeousry; PAULINE MaIER, AMERICAN SCRIPTURE 156 (1998).

112 Leland R. Johnson, "The Suspense Was Hell: The Senate Vote for War in 1812," 65 INDIANA MAGAZINE OF History 247 (1969). 
The Continental Army's and Navy's rapid buildup during the American Revolution did not carry over into the beginning of the nineteenth century. The Founders' opposition to maintaining a standing military left it vulnerable and unprepared when conflict with Britain again escalated thirty years after the Revolution. Yet again, at the onset of war, the now-United-States found themselves dramatically outmanned and out-gunned by Great Britain in a conflict that was to be decided primarily on the seas, where Britain's advantage was strongest. The British Royal Navy, centuries old, had over 500 active warships, 140,000 seamen and, among them, 31,000 trained marines. The U.S. Navy, just eighteen years old, lacked a single battle fleet, had sixteen ships, approximately 5,000 seamen, and 1,000 marines. ${ }^{113}$ It sported only fifteen warships, three of which were ready for action at the war's onset, and no man-of-war class "ships of the line"- the largest and most formidable naval vessels of the time. ${ }^{114}$ It had sold its last warship in 1785, part of a trend away from naval power towards a stronger merchant marine, and only somewhat revived its naval forces in the mid-1790s to protect its merchants against piracy by the Barbary State of Algeria. ${ }^{115}$ The state of its land forces inspired similar unconfidence, as did its foreseeable means of raising funds to augment either within the window of time necessary to be successful. ${ }^{116}$

The U.S. had other perceived advantages that emboldened it: Britain's distraction with the Napoleonic Wars, its distance from friendly dockyards where it could make repairs and resupply, and memories of American victory in the Revolution still clear in the minds of many who were young soldiers at the time of the Revolution but had since risen to the ranks of veteran statesmen. Nonetheless, the Congressional debate over whether to go to war with Britain was bereft of concrete arguments for the United States' military preparedness. Voices of caution such as Rep. Harmanus Bleecker (F-NY) pointed directly to the inadequacy of its resources and viewed them as so insufficient as to make a vote for war treasonous:

\begin{abstract}
"Sir, we cannot go to war within sixty days. I mean not to offend gentlemen, or to rouse their feelings, but it is impossible that we can go to war at the expiration of the embargo... What is the state of your fortifications? Where are your armies, your navy? Have you money? No, sir, rely upon it there will be, there can be, no war, active offensive war, within sixty days... the people know we cannot go to war, at the expiration of the embargo...They think... that for the Government to go to war in our present unprepared state, would be little short of an act of treason." 117
\end{abstract}

113 Naval Battleships in the War of 1812, PBS, http://www.pbs.org/wned/war-of-1812/ essays/naval-battleships/ (last visited Mar. 1, 2019).

114 Id.

115 Michael J. Crawford \& Christine F. Hughes, The Reestablishment of the Navy, 17871801: Historical Overview and Select Biography, Naval Hist. Heritage Command (Jan. 28, 2019, 02:58 PM), https://www.history.navy.mil/research/library/bibliographies/ reestablishment-navy1787-1801.html.

116 Eugene Van Sickle, Financing the War of 1812, Bandy Heritage Ctr., (2014) http:// www.bandyheritagecenter.org/Content/Uploads/Bandy\%20Heritage\%20Center/ files/1812/Financing\%20the \%20War\%20of\%201812.pdf.

11724 Annals of Cong. 1380 (1812). 
John Randolph (DR-VA) joined him in saying,

It would appear astonishing, with the general apathy prevailing in this House, and out of it, that a slumbering Legislature, and a people stupefied under the effects of this powerful political narcotic, the embargo, should have their dreams disturbed by the thought of war. War! when, as a gentleman has justly asked, where are the means to carry it on? ${ }^{118}$

Advocates of war, though equally impassioned, do not seem to have offered any strong contrary interpretation of the U.S.'s abilities to effectively wage war, merely moral assertions that it must do so and mentions that certain measures were already on paper that would make the U.S. more able to supply itself, secure loans, and build its forces over the course of the war once it was begun. As John Rhea (DRTN1) contended on the House floor,

It is urged that they do not believe the United States can go to war. Well, if they do not believe, and will act accordingly, with themselves be it, on themselves be the consequence. Several laws have been enacted, during the present session, bearing strong evidence in themselves that they are preparatory to war, carrying with them also evidence that the United States can go to war at a time when the unprovoked injuries inflicted by a foreign nation renders war necessary. ${ }^{119}$

Rhea and his fellow War Hawks, under the leadership of Speaker Henry Clay (DRKY) and Rep. John C. Calhoun (DR-SC), prevailed in the final vote. Thus, the war commenced with narrow legislative support and mere optimistic assurances that the manpower and resources needed to conduct the war could be acquired over the course of the war. Political opposition to the war would last until its conclusion, with Federalists in New England acting as the most vocal anti-war protesters. Though opposition to the war was not universal in New England, the spirit of dissent that prevailed there would grow so powerful and create such rifts between Washington and New England that President James Madison ultimately decided to remove federal funding for the militias of Massachusetts, Rhode Island, and Connecticut. ${ }^{120}$ Historian Donald R. Hickey writes, "The War of 1812 was America's most unpopular war. It generated more intense opposition than any other war in the nation's history, including the war in Vietnam." 21 That division was fully at work in the legislature. Hickey again: "Federalists everywhere opposed the war, and in Congress they presented a united front against war legislation. The only exceptions were bills to expand the navy and build coastal fortifications, which they considered sound longterm investments in national defense." ${ }^{122}$ The tenacity of

\footnotetext{
Id. at 1385 .

Id. at 1384.

120 Donald R. Hickey, The War of 1812: A Forgotten Conflict, 591 (Bicentennial ed., Univ. of Illinois Press, 2012) (1989).

${ }^{121} \quad I d$. at 255.

122 Id. at xxvi.
} 
antiwar Federalists was such that historians have since viewed it as a major reason for the party's rapid decline after the war. ${ }^{123}$

Despite its tenuous political support, however, the War of 1812 was throughly overseen by both the executive and legislative branches of government. Opposition was fierce, and opposition towards efforts to expand the war may have persisted, but as Hickey's statement suggests, not to the point of neglecting nor obstructing sufficient political oversight of the war nor allowing the U.S. Army and Navy to go unsupplied or unsupported. It is important here to reiterate this model's prediction: that a formal declaration of war enhances legislators' commitment to the outcome of the war by maintaining legislative involvement in its conduct. It is not to say that a considerable number of legislators will not continue to oppose the war; merely that those who voted to enter into war in the first place, having issued an explicit commitment to it, will show a greater propensity to see the conflict through to a favorable end. The War of 1812 demonstrates the resilience of that effect in the midst of a very divisive war.

If anything, the thrust of Federalists' protests was to make the legislature all the more involved in the war's conduct. The Annals of Congress during the war years show regular and attentive involvement by Congress on conduct of the war ${ }^{124}$, war taxes and borrowing ${ }^{125}$, appropriations of supplies and munitions ${ }^{126}$, provisions for the Navy ${ }^{127}$, as well as measures necessary to ensure adequate supplies of new recruits ${ }^{128}$ and the appropriation of compensation and bounties to those aiding in the war effort ${ }^{129}$. Indeed, from debates over Treasury policy to relations with France to the annexation of new territories, scarcely any debate occurs in Congress over this period which is not cast in the light of the war and considered in relation to its success.

In its first military undertaking since the signing of the Constitution, the United States already demonstrated the political rifts that would characterize many conflicts to come, in which Congress strives to shift accountability for the war onto the executive. Even when formally declared, history shows a strong propensity for wars to become popularly identified with the president, if not at congressmen's initiation then certainly with their tacit approval. The War of 1812 quickly became known by critics and Federalist opponents as "Mr. Madison's War," despite the far more open and vociferous pursuit of its initiation by various members of Congress. ${ }^{130}$ However, in contrast to the undeclared conflicts of the twentieth and twenty-first centuries, the effort to shift blame onto the executive was limited to the extent that legislators were either unable or unwilling to distance themselves from the political leadership of America's second war.

123 David Heidler \& Jeanne T. Heidler, The War of 1812378 (Greenwood 2002).

124 E.g., 27 Annals of Cong. 2030-2031 (1814). See, generally, 26 Annals of Cong. (181314).

125 E.g., 26 Annals of Cong. 127-31 (1813); 26 Annals of Cong. 1436-40 (1814); 27 AnNALs of Cong. 1441-1577, 1590-1768 (1814).

126 E.g., 26 AnNals of Cong. 157-63 (1813).

127 E.g., 26 Annals of Cong. 166-67, 318-19 (1813); 27 Annals of Cong. 1800-04, 1808$32,(1814)$.

128 E.g., 28 Annals of Cong. $482-91$ (1814).

129 E.g., 28 Annals of Cong. 517-18 (1814).

130 Donald R. Hickey, The War of 1812: Writings from America's Second War of INDEPENDENCE 709 (2013). 
Where the American Revolution provided a kind of pure case of entirely legislative oversight of a war with widespread approval, the War of 1812 served as both the United States' first military experience with multiple branches of government and the most divisive declared war in its history. Measured against the predictions of our model, however, it appears to hold up. Despite its considerable unpopularity in certain regions of the country, the war enjoyed thorough legislative oversight and was seen through to a favorable draw in which the British embargo was ended and U.S. territorial integrity was maintained; based on Congressional transcripts, the case cannot reasonably be made that Congress was confident enough in the war's outcome as to feel assured of victory ex ante, thus dispelling the selection bias critique; and the heated debate over the war's declaration, giving birth to a muchcontested and highly publicized Congressional faction known as the "War Hawks," makes it unlikely that interested voters would not have known whether the United States had ever declared war or not. Newspapers in the North and mid-Atlantic such as the NationalIntelligencer, Niles Register, Baltimore Whig, and BostonGazette made the prolonged debate over whether to declare war a regular focus of their news coverage and their editorial pages, with the Intelligencer predicting that historians would rank the Twelfth Congress alongside "the immortal Congress" of 1776 for its debates and decision to declare. ${ }^{131}$ In the Republican-dominated South, prodeclaration and subsequently pro-war papers such as the Augusta

Chronicle, Savannah Republican, and Athens Georgia Express dueled with the Federalist Savannah Columbian Museum until wars of words in the newspaper turned to physical violence. ${ }^{132}$ Though estimates of public knowledge of the details of public events are difficult when looking to this period in history, the undisputed predominance of the war debates in headlines throughout the states makes it likely that any citizen with a passable knowledge of the day's top news would likely have been aware of Congress's action to declare. Thus, in summation, the War of 1812 serves as a stress test of the model's predictions as to declared war but a successful one.

\section{iii. The Mexican-American War}

At noon on May 11, 1846, the United States Congress received a message unique in American history up to that time. It was a notification from President James K. Polk that the United States was actively engaged in a military conflict with Mexico, an assessment of the egregious injustices that Polk claimed Mexico had perpetrated against the United States, and a request not that Congress declare war anew but that it vote to authorize a war that was already ongoing. ${ }^{133}$ Time and a fuller revelation of the facts would thoroughly contradict Polk's account of the preceding events, but Congress, limited to the information available to it on that day and unwilling to leave the United States Army without adequate support, found itself cornered into a decision.

Polk's approach was not without careful design. In the preceding weeks and months, he had directed U.S. troops to move beyond the Nueces river into

31 Id. at 47.

132 John E. Talmadge, Georgia's Federalist Press and the War of 1812, 19 J. Southern Hist. 488 (1953).

133 Amy S. Greenberg, A Wicked War: Polk, Clay, Lincoln, and the 1846 U.S. Invasion of Mexico 104 (2012). 
now-western-Texas, intruding into what was at that time recognized as Mexican territory. His claim that "after reiterated menaces, Mexico has passed the boundary of the United States, has invaded our territory and shed American blood upon American soil" was, on every point, an inversion of actual events. ${ }^{134}$ Despite this, when Democratic lawmakers bundled a preamble authorizing funding for the troops with a declaration of war penned by the president himself, Whig opponents hurried unsuccessfully to amend it, finding themselves cornered into either supporting the declaration or opposing the provision of adequate supplies and reinforcement to soldiers on the front line. Much of Congress decried Polk's approach as an act of subterfuge. Garrett Davis (W-KY), declared it to be "our own President who began this war," accusing that "He ha[d] been carrying it on for months."135

There was little to no concern as to whether the United States could be victorious in a war against Mexico. Having learned the lessons of unpreparedness twice, the U.S. Navy would have been well prepared for another war against Great Britain, to say nothing of smaller, poorer, less formidable Mexico. ${ }^{136}$ The Milwaukee Daily Sentinel and Gazette, no advocate of war, referred to Mexico on April 29, 1846, as "a weaker nation on the South," and the description fit. Despite its comparable population to the United States at the time of their respective revolutions, the United States had grown in numbers, wealth, and strength while Mexico had declined, its per capita income falling by half from 1800 to $1845 .{ }^{137}$ Jingoist sentiments aside, there was no uniting ideology or identity in Mexico analogous to the United States, and what began as a short-lived kingdom saw so many coups that the Mexican presidency would change hands more than fifty times from 1821 to 1857 . Stable government was essentially non-existent in its history. More to the point, its instability was roundly acknowledged and understood in America. ${ }^{138}$ President Polk certainly perceived Mexico as a pushover country. Motivated by objective recognition of Mexico's inferior strength, racial beliefs about Mexican inferiority, and ideological commitment to Manifest Destiny, Polk "didn't really believe allout combat would be necessary." 139 Writing to his brother, the president intimated "my impression and hope is, that it will be of short duration... It is probable that the war will be over very soon." 140

Despite great political unrest, the president's approach worked, and the vote to declare "Mr. Polk's War" passed with ninety-two percent support in the House and ninety-five percent in the Senate. Moral doubts as to the war's legitimacy remained strong, and its aggressive character, driven by ideals of Manifest Destiny, was clear. ${ }^{141}$ It would soon be answered with both derision and approbation in an American press that had grown rapidly in the 1800's and made national politicians

134 William Henry Harrison et al., A Compilation of the Messages and Papers of the Presidents 422 (James D. Richardson ed., 1902).

135 GREENBERG, supra note 133 at 104.

136 Id. at 16.

137 Id. at 56.

138 Id. at 57.

139 Id. at 76.

140 James K. Polk to William H. Polk, July 14, 1846, in 11 James K. Polk, Correspondence of JAMEs K. Polk 246 (Herbert Weaver et al. eds. Univ. of Tennessee Press 2009) (1846).

141 Amy S. Greenberg, A Wicked War: Polk, Clay, Lincoln, and the 1846 U.S. Invasion of Mexico 109-110 (2012). 
and war news more accessible to the public than ever before. ${ }^{142}$ Many who voted to declare, however, felt that they could play a greater role in mitigating its costs were they to remain involved and a vote to declare as the best means of securing themselves in that role. As Robert Winthrop (W-MA) stated, "[I]f I can do anything to moderate the War spirit... it must be by exhibiting myself wil[1]ing, when War comes, to vote men \& money for defense." 143

The declaration of war against Mexico was thus perceived by many who voted for it not as an endorsement of the war itself but a profession of their own commitment to support the Army, thereby making perhaps the clearest expression of our model's predictions in action. This commitment was not universal. John Quincy Adams (WMA8) declared it a "most outrageous war" and noted to a fellow congressman that he "hoped the officers would all resign, \& the men all desert, \& he would not help them, if they did not." ${ }^{144}$ However, for legislators in more tenuous political standing than a former U.S. president who had returned to Congress, the act seems to have been effective. Popular awareness of both the conduct and the politics of the war was brought to new heights by the burgeoning of American journalism. Historian Frank Luther Mott writes that "the news coverage of the Mexican War was far more copious than that of any previous war in any part of the world." 145 Another describes it as "the first war to be adequately and comprehensively reported in the daily press." ${ }^{146}$ And public debate over the war ultimately proved consequential in the 1846 elections, signaling the public's attribution of the war to legislators who had voted for it. The struggle to rein in the war's expansionist ambitions and prevent it from becoming a means of expanding slavery westward divided the Democratic Party and gave Whigs control of the House of Representatives in December of 1847 . Legislative opposition by the new Whig majority ultimately proved sufficient to pressure Polk into recalling the U.S. Army from Mexico with the same reluctance that Whigs had shown in declaring the war over a year and a half earlier. The Treaty of Guadalupe Hidalgo was signed on February 2, 1848, ending the war. Polk, damaged by his role in the war, would choose not to seek reelection. Nonetheless, the Mexican-American War is considered to be a decisive victory for the United States. ${ }^{147}$

If the War of 1812 tested the viability of our predictions when the legislature is fiercely and almost evenly divided over a war, the Mexican-American War tests them under conditions of rising and, ultimately, majority legislative opposition to an executive who has clearly and overtly extended himself as the war's unquestionable instigator. In such conditions, it should be even easier for legislators who oppose the war to declare it a case of unmitigated executive overreach and to distance themselves from it as the Federalists did in 1812. However, in the war against Mexico, Whig legislators proclaimed themselves opposed to the war before signing on to the declaration as an act of explicit commitment, consigning to the effort their patriotic support. With Winthrop and others clearly stating their motivation, they implicitly acknowledged the declaration as an expressive device

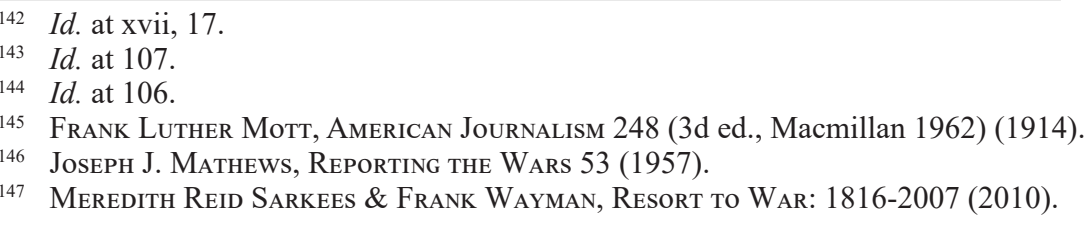


that assigned to them a role in the war's prosecution. In the twenty-one months of war that followed, Congress remained thoroughly involved in the war, to the point of ensuring that it was quickly ended when its course diverged from the agenda supported by a majority of the American people and assumed an unwanted air of imperialism.

This case is the most susceptible yet to the selection bias critique. Democrats can be argued to have been more willing to formally declare war because they knew that the probability of victory was exceedingly high. One might even argue that those Whigs who went along with the vote would have been less willing had Mexico been a more formidable adversary, a la Britain. However, the option of going to war without a declaration appears to have been absent from the debates in this period. America's few experiences with it in the early nineteenth century (discussed below) were highly contentious, and as of the 1840's, the executive branch still behaved as if successfully entering a war depended upon Congress's passage of a formal declaration. Polk may have been willing to send troops into battle before securing legislative approval, but his effort to pen the declaration himself and push it through Congress points to a sense that it was still indispensable, even for such a fait accompli. Going to war and declaring war were still being treated as equivalent, with legitimacy and success in the first dependent upon the latter. Thus, whether to enter into war declared or undeclared does not emerge as a debate in this case, and it would be an anachronous insertion of perspectives from a century later to assume that legislators' choice in 1846 to formally declare war was a function of their exceeding confidence in the outcome rather than a function of consistency and adherence to practices dating to the founding of the country.

\section{iv. The Spanish-American War}

By 1898, Cuba had seen three decades of struggle for autonomy from Spain, ranging from outright war (the Ten Years' War, 1868-1878) to insurgency and organizing by exiled activists for Cuban economic independence. Since 1895, it had been caught in a guerrilla war between the Spanish military and revolutionaries led by José Martí. In consideration for American-owned property in Cuba and the risks posed to American business interests by the war, President William McKinley sent American naval forces to the Havana harbor as a security measure against further instability. ${ }^{148}$ Trade with Cuba had decreased by more than two-thirds as a result of the war, and further externalities to American parties was a leading concern (Ibid. 51). On the night of February 15, 1989, the U.S.S. Maine, at rest in the harbor, exploded and sank, killing two American naval officers and 266 enlisted sailors.

Debate as to the cause of the explosion persists to this day, though the evidence is now seen to weigh against foul play. Louis Fisher, summarizing the findings, writes, "A naval board of inquiry concluded that the blast was caused by a mine placed outside the ship. Release of the board's report led many to accuse Spain of sabotage, helping to build public support for the war. Subsequent studies, including one published in 1976 and later reissued in 1995, determined that the ship was destroyed from the inside, when burning coal in a bunker triggered an explosion in

148 John L. Offner, An Unwanted War: The Diplomacy of the United States and Spain Over Cuba 56 (1992). 
an adjacent space that contained ammunition." ${ }^{149}$ Whatever the cause of the disaster, belief in Spain's responsibility created such an outcry in the United States that, in stark contrast to the Mexican-American War, the United States went to war against the protests and objections of both the speaker of the House of Representatives and the president, who urged caution and restraint. ${ }^{150} \mathrm{McKinley,} \mathrm{whose} \mathrm{experiences} \mathrm{in}$ the American Civil War made him wary of rushing into conflict, was outdone by a powerful pro-war sentiment. ${ }^{151}$ Historian Evan Thomas writes that

In the 1890s, not just [Secretary of the Navy Theodore] Roosevelt but a good slice of his countrymen were possessed by a hunger for war" and that McKinley "was swept aside by hawks like Roosevelt and [newspaper publisher] William Randolph Hearst. ${ }^{152}$

On April 11, McKinley succumbed and asked Congress for authorization for an armed intervention in Cuba but stopped short of asking for a declaration of war against Spain. Congress would exceed the president's request, however, proclaiming Cuba's independence from Spain and issuing authorization for the use of whatever military forces the president deemed necessary to support that cause. McKinley signed the joint resolution on April 20th, Spain declared war against the U.S. on April 23rd, and a declaration from Congress was requested by McKinley and granted on April 25th. In the largest divide between the two houses of Congress over a vote to declare war, the Senate passed the declaration with fifty-five percent support against the House's ninety-eight percent. The lower house, designed by the Founders to be more responsive to current sentiments, proved to be exactly that. Thus, the Spanish-American War can be viewed as unique in two respects: (i.) the striking difference in the level of support for it between the two houses of Congress and (ii.) the fact that it is the first American war in which war was declared by the opposing party first and only secondarily by the United States.

Neither of these factors, however, appear to have manifested in insufficient commitment. The official record of Congressional meetings during this era of American history is sparse, making a detailed account of the frequency of meetings on the topic of the war hard to establish. However, what we know of legislative involvement in the war points to it being a central focus of legislators' efforts at the time. Senator John Sherman of Ohio (R), chairman of the Senate Foreign Relations Committee, established a subcommittee on Cuban affairs and sent Senator Henry Cabot Lodge to Cuba to liaise with and advise the Cuba Libre movement. Meanwhile, Democrats and Republicans literally fistfought one another on the House floor over rules disputes determining who would be the first to pass a resolution recognizing an independent $\mathrm{Cuba} .{ }^{153} \mathrm{By}$ all appearances, the public and at least a majority of their representatives in Congress were unified in their commitment to the new war.

149 Louis Fisher, Destruction of the Maine (1898), Law Library of Congress (2009), http:// loc.gov/law/help/usconlaw/pdf/Maine.1898.pdf.

150 OfFNER, supra note 148 at 131-135.

151 Evan Thomas, The War Lovers: Roosevelt, Lodge, Hearst, and the Rush to Empire (2010).

$152 \quad I d$. at 474 .

$153 I d$. at 238. 
As a result, the already powerful pro-war sentiment that pervaded the country even before the point of declaration complicates the view of a declaration enhancing commitment in the case of the Spanish-American War. In addition to animosity over the explosion of the Maine and the escalating tensions with Spain was what historian Richard Hofstadter has called "the psychic crisis of the 1890s": an eagerness for war and an expansionist fervor widely recognized by historians writing on the period. ${ }^{151154}$ It was an undirected "war fever" that had been building over the preceding years, at first threatening a third war with Great Britain before tensions with Spain arose. The NewY orkTimes headline on December 18, 1895, read "Preparations for War: Country Is Aroused, Want to Fight England: Army, Navy Men Profess Great Eagerness to Go to War, Talk of Invasion of Canada." Contemporary historian Richard Titherington writes of the light-heartedness with which politicians and journalists spoke of war in the lead-up to declaration in $1898^{155}$. And it would be difficult to understand the culture of the SpanishAmerican War without noting the pro-war journalism surrounding it. Though the role of "yellow journalism" in creating the war has been downgraded by historians over the decades, Hearst, Joseph Pulitzer, and newspapers across the country are viewed as having contributed in some measure to the agitation for war, at least in certain major eastern cities. ${ }^{156}$

That spirit was born out in Congress after the explosion in Havana, as politicians scarcely waited for the results of the investigation into its causes before increasing funding and armaments. On March 2, the Senate rushed through a vote for $\$ 50$ million in defense spending to prepare itself for a war that seemed inevitable. ${ }^{157}$ For his caution towards war and increased military funding, Speaker Thomas Reed (R-ME1) was branded in the press as being "Anti-National Defense." 158 And romanticization of the experience would not soon end with the coming of peace. Once the Spanish were defeated, diplomat John Hay reflected on the experience in a letter to Roosevelt as a "splendid little war." ${ }^{159}$ Surely, as in all American wars since 1812 , there was an antiwar movement. ${ }^{160}$ It was, however, a minority view drowned out by calls for conflict and dismissed as, to borrow Theodore Roosevelt's term, a "cult of non-virility."161

The selection bias critique also carries more weight in this case than in the preceding cases, as a high probability of success undoubtedly made the pro-war spirit easier to indulge. As in the war with Mexico, expectations of victory entering the Spanish-American War were strong. Given the military and, specifically, naval advancement of the United States over the 19th century and Spain's decline relative

154 Id. at 190.

155 Richard H. Titherington, The History of the Spanish-American War of 189872 (1900).

156 Ted Curtis Smythe, The Gilded Age Press, 1865-1900 (2003); George W. Auxier, Middle Western Newspapers and the Spanish American War, 1895-1898, 26 Miss. Valley Hist. Rev. 523 (1940).

157 Evan Thomas, The War Lovers: Roosevelt, Lodge, Hearst, and the Rush to Empire 74 (2010).

$158 \quad I d$. at 232.

159 Id. at 12.

160 Piero Gleijeses, 1898: The Opposition to the Spanish-American War, 35 J. Latin. Am. Stud. 681 (2003).

161 Thомаs, supra note 157 , at 73. 
to its former military preeminence, politicians could reasonably expect swift victory at the time of declaration. Cuba, ninety miles from the Florida Keys, was far more accessible to the United States than to Spain, whose forces, already possessing a foothold in its contested territories (Cuba, Puerto Rico, Guam), would have to rely heavily on them for resupply or else wait for reinforcements from across the Atlantic. The United States, both militarily superior and logistically advantaged, could enter the conflict confidently and securely-likely explaining much of the pro-war fervor that preceded the declaration's passage. And public support would manifest far beyond poll numbers. At the outset of the war, the U.S. Army numbered 28,000 soldiers. President McKinley asked for 125,000 volunteers. He wound up with more than one million over a matter of weeks. ${ }^{162}$

The case of the Spanish-American War is relatively ambiguous by comparison to its predecessors. Officially lasting just over six months from the declaration of war against Spain until the signing of the Treaty of Paris on December 10, 1898, it saw only three months of intensive fighting against Spain, resulting in Spain's cessation of Puerto Rico, Guam, and the Philippines to the United States and the independence of Cuba. In that brief span, it is viewed as having effectively ended the Spanish Empire. A summary of events up until the Treaty of Paris would seem to present a clear-cut victory in a formally declared war with thorough legislative involvement, and indeed it is listed by Correlates of War as a decisive victory for the United States. ${ }^{163}$ However, the three year campaign that followed, devoted to securing American control over both the Philippines and Hawaii, comes to look much less like our model of a declared war and much more like the undeclared conflicts of the twentieth and early twenty-first centuries: prolonged occupations with high American casualties and little demonstrable reward. From 1898 to 1903, what became known as the Philippine-American War would see a decline in public support for the war as 4,000 Americans lost their lives battling an insurgency and reports of American atrocities trickled back across the Pacific until Roosevelt, then president, declared an end to all military operations in the Philippines. This stalemated adventure into the Pacific might be cited as evidence contradicting the predictions of our theory of declared wars, but such objections would be misplaced. After the Treaty of Paris, America ceased to be in any formally declared war against Spain, and any excursions pursued beyond December 1898 constitute an undeclared conflict that adheres well to the predictions of that model. That American politicians and military leaders still pursued their objectives in the South Pacific under the auspices of the Spanish-American War does not nullify the fact that in the eyes of the American public war was over, the United States won, and politicians had fulfilled their obligations to the voters. That fact, however, did not prevent politicians from continuing, on an undeclared basis, in a prolonged conflict that looks much more in retrospect like American wars in Vietnam, Afghanistan, and Iraq than like 1812, the Mexican-American War, or the World Wars.

Other unique traits emerge from the Spanish-American War. Given the overwhelming, unprecedented American eagerness for war in the preceding years, the commitment-device-effect of a declaration for legislators appears to be made redundant by strong preferences for war and conquest among both politicians

$162 \quad I d$. at 243.

163 Meredith Reid Sarkees \& Frank Wayman, Resort to War: 1816-2007 (2010). 
and the general public. Commitment devices are rendered rather useless where principals and agents share the same goals with similar fervor, which appears to be the case here. This also provides our first case of an overtly reluctant president being committed to war by legislators eager for conflict. In that sense, it is the reverse of what was observed with President Polk in the Mexican-American War. Though it is our only case study to follow such a pattern, it demonstrates the reciprocality of declarations in committing both branches to the conflict, no matter which is more eager for the fight. It likewise illustrates the commitment of one house of Congress - the Senate - to prosecuting the war even when it passed the declaration by only a very narrow margin.

\section{v. World War I}

By April of 1917, World War I had been underway in Europe for nearly three years. The assassination of Archduke Franz Ferdinand by Bosnian nationalists in 1914 had spurred the issuance of the July Ultimatum, a set of deliberately unacceptable demands, by Austria-Hungary to Serbia. Russia had mobilized against AustriaHungary in defense of Serbia; Germany had declared war against Russia; tensions boiled over into conflict between Germany and neighboring France and Belgium; and Great Britain had entered to defend the neutrality of Belgium, bringing every major power in Europe into the fray. President Woodrow Wilson had won reelection in 1916 on the basis of his having kept the United States out of the war, in a state of "armed neutrality," but the sinking of the passenger ship Lusitania by a German U-boat in 1915 and Germany's violation of commitments to not engage in unrestricted submarine warfare made America's abstinence increasingly difficult to maintain. The revelation of the Zimmerman Telegram, in which Germany solicited Mexico's entry into war against the United States, proved to be the final straw. Wilson would present the telegram to the American public and secure Congress's support to enter the war on the side of the Allied Powers. Congress declared war on April 6, 1917.

The declaration of war against Germany passed with strong support: ninetythree percent of the Senate, eighty-eight percent of the House. Coincident with the Zimmerman Telegram and resumed U-boat activities were economic considerations that favored supporting the Allies, whom American financiers had already kept afloat with sizable lines of credit. Should they default, politicians feared that overexposed American banks might be destabilized. When Wilson consulted his cabinet on the question of declaring, he found unanimous support for entry. ${ }^{164}$ Gompert et al. note the lack of clarity in the historical record as to whether popular opinion followed or preceded Wilson's decision. ${ }^{165}$ There had been, since the outbreak of war in Europe, strong antiwar activism counterbalanced by others who agitated for American involvement, but whether Wilson sensed support for entry increasing and followed public opinion or chose to take the initiative is not readily clear. Whatever the order of events, once war was declared, Wilson found a largely committed public who were, at least at the outset, convinced of the war's probable necessity.

\footnotetext{
164 David C. Gompert et al., Woodrow Wilson's Decision to Enter World War I, 1917, in Blinders, Blunders, and Wars: What America and China Can Learn 75 (2014).

165 Id. at 76.
} 
The European powers had entered into World War I in 1914 confident that it would be a brief endeavor without devastating costs. Wilson, despite his acting three years later, believed the same of American entry. To his credit, he was right, though not for all of the reasons he presented. In arguing for entry before Congress, Wilson expressed the arbitrary view that though particular leaders agitated for war, all the peoples of Europe truly wanted peace and found themselves caught beneath the machinations of their rulers. In arguing this, Wilson's estimation of human nature was more assumed than thoroughly defended. His second reasoning, however, was decidedly more practical. From Gompert et al, "Wilson did not expect that large-scale U.S. forces would actually be needed to fight on the Western Front; rather, he figured that political, financial, and material support would tip the balance decidedly in favor of the Allies." ${ }^{166}$ Given the grinding stalemate of the war at the time of American entry and its mere nineteen months duration afterwards, Wilson was correct to believe that the U.S. would tip the scales in favor of a quicker resolution. What he either underestimated or downplayed was the considerable cost of lives and resources that ending it would require.

In the years leading up to American entry, a number of prominent American leaders in government and business, including Theodore Roosevelt and former Secretaries of War Elihu Root and Henry Stimson, had led what was known as the Preparedness Movement, an effort to fund and organize American readiness should it ultimately need to enter the war in Europe. ${ }^{167}$ Their training camps for potential wartime officers, however, were small relative to what America would soon require. American military preparedness had dwindled since the beginning of the 20th century, leaving the United States with the lowest troop and supply levels since the Civil War. The U.S. Navy was widely viewed as unprepared for conflict on the scale that would be demanded. The U.S. Army numbered roughly 200,000 men, with 80,000 of those in the National Guard-compared to Germany's 11 million troops, Austria's 7.8 million, and Britain and France with roughly 8 million each. ${ }^{168}$ Regardless, the National Defense Act of 1916 expanded the governments manpower and resources, allowing it to begin organizing for the fight, and Wilson would rely heavily on conscription to fulfill the numbers required to defeat the Central Powers. A greater obstacle would be filling the ranks of officers able to provide the skilled battlefield leadership needed to win. ${ }^{169}$

Congress was, for their initial reluctance, actively involved in policies supporting military preparedness and supply even before the declaration of war. Rep. James Hay (D-VA7), an ardent promoter of peace and an opponent of conscription, was ultimately persuaded to support some of the Wilson administration's preparedness plans. Rep. David H. Kincheloe (D-KY2) opposed increasing the Army's ranks prior to war but, anticipating the plans of President Dwight Eisenhower decades later, advocated for the construction of a national highway system as a matter of national defense (Herring, 1964). Congress voted to give the federal government the

166 Id.

167 George C. Herring, James Hay and the Preparedness Controversy, 1915-1916, 30 J. SOUTHERn Hist. 383 (1988).

168 Michael Clodfelter, Warfare and Armed Conflicts: A Statistical Reference to Casualty and Other Figures, 1618-1991 (1992).

169 Mitchell Yockelson, They Answered the Call: Military Service in the United States Army During World War I, 1917-1919, 30 Prologue Magazine 228 (1998). 
authority to call up the National Guard in times of crisis. Once war began, Congress would be actively engaged in military and domestic policy-sometimes for better and sometimes for worse. Benjamin Kleinerman writes that "The World War I Congress, under the prodding of Woodrow Wilson, authorized all those powers Wilson thought might be necessary to fight the war." Wilson repeatedly sought, and in some cases received, legislative approval for expansions of his executive powers in ways justified by but not limited to wartime necessity. Through the Espionage Act of 1917 and the Sedition Act of 1918, Wilson sought to suppress dissent and criticism of the war, asking Congress for "authority to exercise censorship over press" in order to silence "persons in a position to do mischief." ${ }^{170}$ Congress, though at times permissive of Wilson's requests, would counter him on others, maintaining its role as a foil to executive discretion in wartime policy.

Means aside, the war was successfully brought to an end, at least for the moment. Correlates of War lists it as a victory for the United States. ${ }^{171}$ The Paris Peace Conference and the Treaty of Versailles allowed Germany to conditionally surrender, subject to its acceptance of guilt for the war and its payment of reparations. Placing the seeds of World War II in the Treaty and its provisions is probably the most well-trodden exercise in process tracing in all of international relations and political history, but for that moment in history, the resolution it achieved meets the standard put forth by this model, being both favorable and - for a generationdecisive. The continued development of the American print media by this time and the element of the draft makes it difficult to imagine that a majority of the electorate would be unaware that war had been declared. Thus, World War I appears to pass our model's four-part test: a highly involved legislature, a decisive and favorable resolution, no prevalent ex ante view that victory was relatively certain, and widespread public awareness that Congress had declared war.

\section{vi. World War II}

The 1930s were, economically, a lost decade for the United States, the Great Depression having left the country thoroughly depleted. By 1941, for the first time since the stock market crash of 1929, U.S. GNP was returning to its precrash levels and had begun to show signs of stability and growth. ${ }^{172}$ Meanwhile, as in 1917, the United States struggled to remain uninvolved in another world war that had spread across Europe, Russia, North Africa, and Asia. However, when Axis Powers' animosity reached a boiling point over the United States' Lend-Lease Program, the American renunciation of its trade deal with Japan, and its refusal to continue selling Japan airplane fuel, the United States could avoid war no longer. On December 7, 1941, the Empire of Japan bombed the American base at Pearl Harbor in Hawaii. Unlike at the onset of World War I, the United States had been deliberately and unambiguously attacked. It wasted no time in responding. President Franklin Delano Roosevelt issued the most widely heard radio broadcast in history on December 8 before a joint session of Congress, making his appeal

170 Benjamin A. Kleinerman, In the Name of National Security, in ThE Limits of Constitutional Democracy (Jeffrey K. Tulis \& Stephen Macedo eds., 2010).

171 Meredith Reid Sarkees \& Frank Wayman, Resort to War: 1816-2007 (2010).

172 Gross National Product, 1929-1941, Not Seasonally Adjusted, FRED St. Louis Fed. https://fred.stlouisfed.org/series/GNPA. 
to legislators for a formal declaration of war against Japan. Over 81 percent of Americans listened live to his speech. ${ }^{173}$ Congress passed the resolution within an hour of Roosevelt's address. Germany, in solidarity with its ally, declared war against the United States on December 11, and the United States responded in kind the same day with a declaration against both Germany and Italy.

The decision to enter war with Japan was, in this case, thrust upon American politicians. An attack of such scale and deliberation would be impossible to ignore. The option by Roosevelt's administration to declare war against Germany was initially undecided, as his advisors deliberated over whether to wage a singular war in the Pacific against Japan or to divide America's efforts and aid ally Britain on the European front. That the decision was effectively made for them by Germany's choice was momentous. Roosevelt advisor John Kenneth Galbraith remembered:

We could have been forced to concentrate all our efforts on the Pacific, unable from then on to give more than purely peripheral help to Britain. It was truly astonishing when Hitler declared war on us three days later. I cannot tell you our feelings of triumph. It was a totally irrational thing for him to do, and I think it saved Europe. ${ }^{174}$

With war on two fronts, the United States needed to mobilize rapidly if it was to be successful. Its politicians wasted no time.

Whether it is creditable to budgetary prioritization or to the Founding Fathers' establishment of a culture averse to a large standing military, in every war in American history yet discussed, the United States has found itself significantly diminished from its previous military standing by the time of the next war. World War II is somewhat of an exception. Military strength stood at roughly 250,000 in 1940 - almost unchanged since 1920. After the fall of France, it began to accrue forces and supplies in case Europe's war should become its own. When the war ended, three-and-a-half years after Pearl Harbor, 16.1 million Americans had been drafted or volunteered to serve in the Armed forces. ${ }^{175}$ In the interim, the United States Congress played an active role with the president in setting troop levels, directing foreign and military policies, providing adequate funding and supply, and in all respects enhancing the United States' capacity to make war.

Historian David L. Porter, in his analysis of the seventy-sixth congress, which presided from 1939 to 1940 , looks to the congressional records and finds a more active role played by Congress in the lead-up to World War II than that played by the president. Citing Congress's revision of neutrality legislation, its provision of a loan to Finland, its support of a peacetime draft, and a shift from isolationism to internationalism to interventionism, he gives a leading role to Congress in readying American forces for war. ${ }^{176}$ The creation of the Senate Special Committee

173 Robert J. Brown, Manipulating the Ether: The Power of Broadcast Radio in Thirties America 117-20 (1998).

174 Gitta Sereny, Interview with John Kenneth Galbraith, in Albert Speer: His Battle With TRUth 267-268 (Knopf 1995).

175 Bernard Rostker, World War II, in Providing for the Casualties of War: The American EXPerience Through World War II 175 (2013).

176 David L. Porter, The Seventy-Sixth Congress and World War II, 1939-1940 (1979). 
to Investigate Gasoline and Fuel Oil Shortages and the Special Committee to Investigate the National Defense Program as well as the joint Conference Committee on S. 2208 and the joint Reduction of Nonessential Federal Expenditures indicate structural changes designed to provide special attention to the war effort, and the strong war orientation of even committees not typically related to national defense such as committees on Public Buildings and Grounds, Judiciary, Interstate Commerce, and Education and Labor reveal the salience of the war to all legislative bodies. Indeed, official records of roll call votes reveal thirty-three "outstanding" war-related Senate votes by the 77 th Congress prior to Pearl Harbor. ${ }^{177}$

However the credit is to be apportioned, both branches played a role in ensuring that the war was conducted with adequate supply. Harrison writes that, "[b]y mid-1942 war contracts had been issued to a sum exceeding the value of the 1941 gross national product," and the United States would be the only major war economy to never rely heavily upon external supply, demonstrating a level of productivity unmatched by the other major powers, all while using a lesser percentage of its population in the military and war economy. ${ }^{178}$ Beyond funding and the apportionment of manpower and supplies, legislators played an active role in ensuring that war policy was effectively conducted. The 77th Congress passed the Lend Lease Act and established the Senate Special Committee to Investigate the National Defense Program, alternatively known as the "Truman Committee," to oversee war production and ensure efficient use of wartime resources. Indeed, contemporary reports suggest that there was at least as much criticism of Congress for being too involved in the administration of the war effort as there was for it being too lax. ${ }^{179}$ Its level of involvement shows no sign of having waned; in March of 1944, Congress established a special House committee of 23 members to formulate a postwar military policy and determine the method of consolidation of the armed services. ${ }^{180}$ To the end, legislators expressed concern for executive overreach. A Senate resolution of February 7, 1944, called for a general investigation by the Senate Judiciary Committee into the Roosevelt administration's use of executive orders, regulations, and directives ${ }^{181}$, and the Smith committee, which was established in 1943 to investigate "activities of the executive agencies beyond the scope of their authority" recommended in November of 1944 that broad changes be enacted within the legislature to expand its control of bureaucracies relative to the Executive Branch. "The framers... of the Constitution," it wrote, "never contemplated that the Legislative Branch... would become a mere ratifying body of a supreme Executive will." 182

177 Record Votes in the 77th Congress (First Session), in EDItorial Research RePorts 1941453 (1941), http://library.cqpress.com/cqresearcher/cqresrre1941121600.

178 Mark Harrison, Resource Mobilization for World War II: The U.S.A., U.K., U.S.S.R., and Germany, 1938-1945, 41 Econ. Hist. Rev. 171 (1988).

179 Congress and the Conduct of War, CQ ReSEARCHER, (1942), http://library.cqpress.com/ cqresearcher/document.php?id=cqresrre 1942082400, (last visited Sept. 24, 2017).

180 Record of the 78th Congress (Second Session), in EDITORIal Research RePorts 1944, at 363-416 (1944), http://library.cqpress.com/cqresearcher/cqresrre1944122000 [hereinafter 78 th Congress].

181 S. Res. 252, 78th Cong. (Feb. 7, 1944).

18278 th Congress, supra note 180. 
The result of the United States' military and political efforts was the most decisive victory in its history. The Allies won the war on all fronts, and the U.S. not only turned the course of the war by its entry but ultimately secured the unconditional surrender of the European Axis powers and Japan. ${ }^{183}$ In the process, as a result of its own buildup, Britain's loss of numerous territories, and the role that its diplomats played in framing the subsequent peace, the United States emerged as the most powerful nation in the world. Here again, it seems, the predictions of the model are largely borne out in terms of legislative involvement and a decisive, successful outcome. Its weakest points as a demonstration of the model's predictions are (i.) that, as in World War I, the measures taken prior to the time of declaration to prepare the U.S. cannot be seen as arising from the declaration itself but rather as part of an already existent spirit of support for the effort and (ii.) that, while U.S. forces and supplies may have been scant at the outset of the conflict, leaning on this fact too heavily disguises the immense productive potential available to be realized from its then-immobile resources. The first point does not negate the model so much as obscure the effect of declarations when support and morale are already high, and the second is well taken, though a war that is declared within twenty-four hours of a devastating surprise attack can hardly be said to have been declared in a spirit of exceeding confidence. In the end, it seems we have yet another case of an open and formal declaration, a high degree of legislative commitment, and a decisive victory.

\section{B. UNDECLARED WARS}

Those cases in which the United States has formalized a military engagement with a declaration of war constitute a small minority. Relative to these six cases of formally declared war, in thirteen instances the U.S. Congress has authorized military operations against foreign governments or in defense of American trade, and in seven instances it has authorized the engagement of American troops under United Nations Security Council resolutions with provisions for funding made by Congress. In at least 125 other cases, an American president has led a military venture without congressional approval or appropriations. ${ }^{184}$ The instances are far too numerous to discuss the vast majority of them, so for the sake of thorough analysis I will focus on the more notable undeclared conflicts since World War II. They are of interest not simply because of their recency but because of the trend that they establish: a sixty year pattern of large, costly, deadly ventures in which the United States Congress gives its authorization on either an ex ante or ex post basis, large numbers of troops are committed to the conflict, but the final result is generally either ambiguous or unfavorable.

The 5-0-1 record of the United States in declared wars finds a stark contrast in the 1-4 record of moderate-to-large-scale undeclared engagements over this period. In exchange for that poor record, by this author's calculations using official

83 Meredith Reid Sarkees \& Frank Wayman, Resort to War: 1816-2007 (2010).

184 John C. Yoo, Memorandum Opinion for the Deputy Counsel to the President: The President's Constitutional Authority to Conduct Military Operations Against Terrorists and Nations Supporting Them (Sept. 25, 2001), available at https://www.justice.gov/sites/default/files/olc/opinions/2001/09/31/op-olcv025-p0188_0.pdf. 
data, the United States has suffered 97,311 casualties. ${ }^{185}$ In fiscal outlays, it spent over $\$ 1.18$ trillion $(2011 \$$ ) on the Korean War, Vietnam War, and Gulf War, not including the years of medical benefits and government services that are still accruing as a result of those wars. ${ }^{186}$ And the twenty-first century conflicts in Iraq and Afghanistan are projected to be the most expensive in its history, costing \$4-6 trillion once all resultant future military benefits are included. ${ }^{187}$ In addressing these very costly cases throughout this section, we will find that the predictions of this theory of undeclared wars are not perfectly born out in all instances. The Persian Gulf War stands out as a notable success despite never having been formally declared. However, the claim that declared wars are more likely to be seen through to decisive ends is summarily validated.

We will also see that the selection bias critique is undermined by a litany of instances contradicting its predictions. If, as that critique proposes, legislators are more inclined to formally declare war when they know that victory is highly probable, then we should have observed many more formal declarations than we have over the period in question. Whatever the degree of confidence felt by American politicians in the wars analyzed in the previous section, the selection bias critique requires us to believe that they were more confident going to war against Great Britain (twice), Mexico, Spain, Germany (twice), Italy, and Japan than against the opponents it has faced in the last six decades. Whereas debate can be entertained as to the relative military strengths of the Allied and Axis Powers in 1941, it is inconceivable to argue that the United States should have seen itself as militarily inferior to or equalled by North Korea, the North Vietnamese, the Hussein regime in Iraq, the Taliban in Afghanistan, or other adversaries not discussed here such as Libyan Arab Jamahiriya or Shia and Druze militias in Lebanon. Yet no formal declarations were passed or proposed. Thus, that argument appears to be further weakened by a lack of ambition on the part of legislators to seek easy credit for wars that were viewed, ex ante, as easily winnable.

In an attempt to validate the theory of undeclared conflicts, I will examine the following cases with an eye towards signs of deficient legislative oversight, unchecked executive discretion in the conflict's management, more successful efforts by legislators to shift blame onto the executive branch, and largely indecisive or unfavorable resolutions.

\section{i. Korean War}

In August of 1945, in an agreement with the United States designed to end World War II in the Pacific, the USSR declared war against Japan and pushed Japanese forces out of the northern half of the Korean peninsula as far as the 38th parallel. Following the American defeat of Japan that same month, the Soviets would hold the conquered territory in the North as the South emerged under a new, American-

185 U.S. Dep‘t of Veterans Aff., America’s Wars (2017), https://www.va.gov/opa/ publications/factsheets/fs_americas_wars.pdf.

186 Stephen Daggett, Cong. Research Serv., RS22926, Costs of Major U.S. Wars 2 (2010).

187 Linda J. Bilmes, The Financial Legacy of Iraq and Afghanistan: How Wartime Spending Decisions Constrain Future National Security Budgets, Hks Faculty Research WORKING PAPER Series Rwp13-006 (2013). 
led government. By 1948, Korea was operating under two separate governing systems - one communist, one free. On June 25, 1950, in an attempt to unify the peninsula under communist leadership, Northern forces supported by the Soviet Union and China commenced an invasion of the South, immediately provoking a response by the recently established United Nations Security Council. UNSC Resolution 82, issued that same day, demanded an immediate end to hostilities by North Korea and called upon member states to "render every assistance to the United Nations in the execution of this resolution and to refrain from giving assistance to the North Korean authorities." ${ }^{88}$ UNSC Resolution 83, adopted June 27 , formally declared the attack to be a breach of the peace and recommended that "Members of the United Nations furnish such assistance to the Republic of Korea as may be necessary to repel the armed attack and to restore international peace and security in the area." 189

In response to these developments, the administration of U.S. President Harry S. Truman exercised an unprecedented degree of unilateral activism, quickly committing the United States to leadership of the U.N.'s mission via naval and air strikes and soon engaging over 326,000 American troops to the Korean peninsula in the name of containing communist aggression. ${ }^{190}$ Perhaps more surprising was Truman's success in amassing such troop levels in a matter of months and without significant Congressional challenge. Political scientist Stefan M. Brooks describes this as the result of a growing culture of legislative deference in the wake of WorldWar-II and Franklin Roosevelt's dramatic accruance of executive powers:

"Throughout most of American history, Congress was the predominant power in the U.S. government. In the 1930s, however, owing first to the Great Depression and then to World War II, the power and responsibility of the president increased dramatically and eclipsed that of Congress, particularly in foreign affairs. This trend became even more pronounced with the coming of the Cold War in the late 1940s. Congress increasingly seemed to defer to the actions of the president with little, if any, critical debate or oversight. President Harry S. Truman broke new ground by committing U.S. troops to the Korean War in 1950 with no prior congressional approval or debate and no formal declaration of war."'191

Undoubtedly, the environment of fear and suspicion towards communism that prevailed in the immediate aftermath of World War II played a role in the ease of attaining domestic acquiescence to U.S. action. Also instrumental was Truman's unequivocal insistence during the onset of the conflict that "[w]e are not at war."192

188 S.C. Res. 82 (June 25, 1950).

189 S.C. Res. 83 (June 27, 1950).

190 David Rees, Korea: The Limited War 23 (1964).

191 Stefan M. Brooks, Imperial Presidency, in The Encyclopedia of the Vietnam War: A Political and Military History (Spencer C. Tucker ed., 2d ed., ABC-CliO 2011) (1998).

192 Harry S. Truman, The President's News Conference of June 29, 1950, Teaching American HistoRY, https://teachingamericanhistory.org/library/document/the-presidents-newsconference-of-june-29-1950/. 
In rhetoric that foreshadowed the later Bush administration's downplaying of unrecognized actors in the War on Terror, Truman dismissed the U.N. intervention as a "police action" that was "going to the relief of the Korean Republic [sic] to suppress a bandit raid." 193 Whatever the merits of the debate over whether American voters were acutely aware of the role of Congress in the United States' declared wars, it can be said confidently that an American president actively engaging a significant number of U.S. forces abroad while emphatically insisting to the public that the U.S. was not at war is a distinctive move away from its earlier approach. Truman's motives are, in retrospect, clear. The United States having been a late entrant to the conflict in both world wars, the Truman administration felt the need to ensure that the conflict on the Korean peninsula, with the USSR and China as North Korea's backers, did not turn into either World War III or a wholesale destruction of newly established South Korea. Also at issue was the possibility that South Korea, if conquered, could become a base for launching expansionary measures against newly reconstructed Japan. ${ }^{194}$

As a product of these concerns and America's newfound status as global superpower, the Truman administration ensured that the U.S. would provide the vast majority of the U.N.'s peacekeeping forces. As noted, it did so unilaterally at first, with little to no participation by members of Congress. Records show that on June 27, 1950, two days after North Korean invasion, President Truman invited a small number of congressional leaders (the exact number not being preserved in the record) to the White House not to ask for permission but to inform them of his chosen course of action with respect to Korea, with every member of that delegation submitting to the president's plan after only a few clarifying questions. ${ }^{195}$ The newly established framework of the United Nations appears in the record to have sufficed for these legislative leaders in replacing any need for congressional debate or authorization, no mention having been made of bringing the issue before their committees nor the floors of their chambers before military measures were taken. In response to legislators' passivity, with troops already mobilizing, on June 30 Truman considered seeking congressional approval on an ex post basis but apparently felt no need for it. With public support for the engagement at that time very high and Truman not wanting to invite criticism from Republicans, he merely dispensed with the process of securing Congress's support. In his own words, "I just had to act as Commander in Chief and I did." 196

In a scene that would repeat in the Vietnam and Iraq Wars, a legislature that passively accepted entry into a conflict, never exerted any notable effort to avoid entry, nor challenged the constitutional authority of the president to initiate a conflict would go on to challenge the sitting president on the merits of entering it after the fact (if not always wanting to deeply involve themselves in improving its administration). In each case, entry into the conflict is passively accepted without

193 Id.

194 Yông-jin Kim, Major Powers and Korea 46 (1973).

195 Harry S. Truman, Notes Regarding Meeting with Congressional Leaders, June 27, 1950, Harry S. Truman Presidential Library \& Museum (June 27, 1950),

https://www.trumanlibrary.gov/library/research-files/notes-regarding-meetingcongressional-leaders.

196 Barton J. Bernstein, The Truman Administration and the Korean War, in The TrumaN Presidency 426 (Michael J. Lacey ed., 1989). 
issue only to be made contentious later in response to public dissatisfaction. In each case, however, with Korea establishing the model, legislators seem, at the onset of conflict, wholly willing to engage in the sort of implicit Coasean bargain described by Sidak.

Consistent with later cases, legislators of the 80th and 81st Congresses would abandon their former passivity when the war turned unpopular, shifting blame onto the executive while downplaying their own early acceptance of it. Following Chinese entry into the war on October 19th, public support dissipated, falling from favorability ratings in the high seventies to below fifty percent and fluctuating well below fifty percent for the duration of the war. By October of the following year, fifty-six percent of Gallup respondents agreed with the position that Korea was a "useless war," and fifty-one percent in March of 1952 called it a mistake. ${ }^{197}$ Congress responded to the fall in approval ratings, demanding answers to questions it had not asked at the start of the conflict and displaying a sudden anger that it had not been granted a greater role in the decision to enter. Buchanan writes that "Republicans, who had initially offered only token resistance, began to complain that Congress had not been consulted." 198 They soon proposed the Bricker Amendment, designed to constrain the president's military discretion, but only after hostilities in Korea had been concluded, not during. Despite having never insisted upon national security committee hearings and oversight in June of 1950, after public support soured in the fall both the SFRC and SASC increased the number of their hearings dramatically in 1951 (from about 65 to roughly 110 for the SASC and about 50 to around 75 for SFRC) ${ }^{199}$ However, that support was not lasting, and though the war waged on, the change in oversight appears to have returned to its previous levels in 1952. ${ }^{200}$ Legislators' interest in oversight thus appears to be more susceptible to the rise and fall of popular opinion when Congress has not given its imprimatur from the outset and the president has assumed full ownership of the conflict's initiation.

In keeping with our model's predictions, Congress strove to shift all blame for the war's negative developments onto the president. Republican Senator Robert Taft $(\mathrm{OH})$, a presidential aspirant, strove to carve out an executive image for himself by frequently criticizing both Truman and General Douglas MacArthur for the progress of the war. The criticism of Taft and others proved effective as Truman's approval ratings fell precipitously, vacillating in the high twenties to low thirties from January 1951 onward, giving him an average approval rating of $36.5 \%$ in his second term and a low of twenty-two percent in February of 1952, leading him to decide not to seek reelection in November of that year. ${ }^{201}$ Truman's fellow Democrats would not be immune from the war's political costs, losing both the House and Senate in 1952 but regaining both in 1954. In an unintended homage to their nineteenth century predecessors, legislators soon dubbed the conflict "Mr.

197 John E. Mueller, War, Presidents, and Public Opinion 51 (1973).

198 Bruce Buchanan, Presidential Accountability for Wars of Choice, 22 Issues Governance Stud. 1, 4 (2008).

199 Linda L. Fowler, Watchdogs on the Hill: The Decline of Congressional Oversight of U.S. Foreign Policy 51 (2015).

200 Id.

201 Presidential Approval Ratings - Gallup Historical Statistics and Trends, Gallup, http:// www.gallup.com/poll/116677/presidential-approval-ratings-gallup-historicalstatisticstrends.aspx, (last visited Sept. 23, 2017). 
Truman's War." 202 Unlike those predecessors, however, they had been complicit facilitators in the war's initiation and found their distaste for the conflict only after a series of negative developments and an upwelling of public dissatisfaction.

America's first instance of conflict without declaration in the post-WorldWarTwo era appears, by all accounts, to validate our theory of undeclared conflicts. It was a costly war at $\$ 341$ billion in 2011 dollars and 54,246 American deaths. ${ }^{203}$ It was initially met with legislative passivity only to later see congressmen and senators vehemently - and successfully - shift accountability to the executive branch. Finally, and troublingly, it was an indecisive conflict, listed as a "Stalemate" by Correlates of War ${ }^{204}$ and "Not Successful" by Feaver and Gelpi. ${ }^{205}$ A stark contrast to the total defeats of Germany and Japan less than eight years prior, it ended in a stalemate at the 38th Parallel, with half of Korea remaining subsumed under communist dictatorship. To this date, the Korean War never officially ended at all but has remained at a tenuous ceasefire for over sixty years. Despite its considerable costs, fatalities, political confusion, and unsatisfying resolution, however, the Korean War would not prove to be a learning experience for the United States. Rather, its troubles were already being replicated just a few years hence.

\section{ii. Vietnam War}

If Korea established the model of costly, indecisive, and feverishly debated military engagements that have characterized the post-World-War-Two era, the Vietnam War epitomized it. Officially lasting nine years, from the 1964 Gulf of Tonkin Resolution to the withdrawal of U.S. forces from Vietnam under the 1973 Paris Peace Accords, it began inauspiciously as part of a gradual escalation of U.S. involvement in Southeast Asia. In 1955, President Dwight Eisenhower sent 700 soldiers to Vietnam in 1955 as "military advisors" in support of the South Vietnamese, who were struggling to resist a rising communist regime in the North. In 1961, the incoming Kennedy administration increased the number of Special Forces troops and advisors from 794 to 959. In 1962, their numbers were increased dramatically to 8,498, with 53 having been killed. By the end of 1963, the number of American military personnel in Vietnam rose to 15,620, and a clear trend of rapid escalation had begun. ${ }^{206}$ Whatever the preferred terminology for American forces in country, the United States was becoming deeply involved in an intranational conflict on the other side of the globe.

As American troop levels in Vietnam rose throughout the early 1960's, public records do not reveal a corresponding increase in Senate national security committee hearings. Significant upticks in the frequency of oversight hearings didn't begin until 1964, when the Gulf of Tonkin Resolution was passed, authorizing U.S. military action against the North Vietnamese in response to alleged firings against

202 Donald R. McCoy, The Presidency of Harry S. Truman 222 (1984).

203 Stephen Daggett, Cong. Research Serv., RS22926, Costs of Major U.S. Wars 2 (2010).

204 Meredith Reid Sarkees \& Frank Wayman, Resort to War: 1816-2007 (2010).

205 Peter D. Feaver \& Christopher Gelpi, Choosing Your Battles: American CivilMilitary Relations and the Use of Force 140 (2004).

206 Tim Kane, Global U.S. Troop Deployment, 1950--2003, Heritage Foundation (Oct. 27, 2004), http://www.heritage.org/defense/reportglobal-us-troop-deployment-1950-2003. 
U.S. Navy ships off the coast of Vietnam. To be sure, after the Resolution both the SFRC and SASC increased oversight subtly, relying on closed-door executive hearings rather than the sort of public hearings likely to attract press and public awareness. Neither committee held a public hearing on Vietnam until 1966, even as Operation Rolling Thunder commenced bombing North Vietnam. ${ }^{207}$

As in the Korean War, the frequency of legislative hearings tracked poll numbers, rising as public approval of the war plummeted and it assumed a central role in American national politics. Fowler notes that from 1964 to 1975, the point of final withdrawal from Vietnam, the SASC and SFRC conducted 345 days of hearings on national security, 137 of which were public and 208 of which were closed-door executive hearings. Ninety percent of Armed Services' 147 meeting days were about crises and scandals related to Southeast Asia, as were sixty-three percent of Foreign Relations' 198 meeting days. As of the spring of 1966, though, the vast majority of Senate oversight hearings had been conducted behind closed doors. ${ }^{208}$ Politicians' approach seems to have been one of getting involved without drawing attention to their involvement. Whatever the frequency of hearings, however, legislative involvement does not appear to have been at any point an effective brake or a meaningful challenge to the executive branch's escalation. Troop levels grew every year from 1959 to 1968, with over half a million troops committed to the conflict in that time. As Brooks remarks, "Expansion of the war was achieved largely without much congressional involvement. Certainly there was virtually no congressional oversight leading up to the war in $1965 .{ }^{\prime 209}$ As for the legislature outside of SASC and SFRC, after the Gulf of Tonkin Resolution passed in 1964 neither house of Congress would cast roll call votes on the war in Southeast Asia until 1970, when the Cooper-Church Amendment, which blocked funding for military personnel and air operations in Cambodia, passed the Senate only to be defeated in the House. ${ }^{210}$

By the spring of 1966, the weight of the war's growing unpopularity fell considerably on the executive. SFRC Chairman J. William Fulbright (D-AR) publicly and repeatedly invoked the term "credibility gap" to describe his committee's lack of trust in executive branch officials and commenced a series of "educational" public, televised hearings in order to call out the administration for its alleged secrecy, with the irony of that committee's disinterest in the conflict two years earlier going seemingly unmentioned. Correspondingly, President Johnson's approval ratings regarding handling of the war fell from 63 percent to 49 percent in response to the scrutiny. ${ }^{211}$ The president was indeed "owning" the war, and it would continue to be reflected in such ratings. Whereas Johnson's average overall approval rating during his first term, November 1963 to January 1965, was 70.1\% with a high of $79 \%$ in February 1964, it fell precipitously to $50.3 \%$ in his second term, January 1965 to

\footnotetext{
207 Linda L. Fowler, Watchdogs on the Hill: The Decline of Congressional Oversight OF U.S. Foreign Policy (2015).

208 Id. at 65.

209 Stefan M. Brooks, Imperial Presidency, in The Encyclopedia of the Vietnam War: A Political and Military History 529 (Spencer C. Tucker ed., 2d ed., ABC-CLIO 2011) (1998).

210 FowLER, supra note 207, at Xv.

211 Vietnam Hearings,: 1964-Present, United States Senate, https://www.senate.gov/ artandhistory/history/minute/Vietnam_Hearings.htm, (last visited Sept. 23, 2017).
} 
January 1969, with a low of $35 \%$ in August 1968. Despite periodic variations, its trajectory throughout both terms was one of steady decline. ${ }^{212}$ Likewise, in November of 1964, one year after Kennedy's assassination and Johnson being sworn in, overall public trust in government reached a high that has never been achieved again, with seventy-seven percent of Americans surveyed by Pew Research Center reporting that they have confidence in the federal government "just about always" or "most of the time." Over the course of the war, that figure would fall every year. When the last American troops were withdrawn from Vietnam, it was less than half of its original value at thirty-six percent. Distrust rose symmetrically over the period, increasing from twenty-two percent in 1964 to sixty-two percent in 1974, with Vietnam cited as a leading cause alongside the Watergate scandal. ${ }^{213}$

Due to the powerful effect of public outrage, the Vietnam War would not go completely unattended to by legislators, but it nonetheless bears out the theory of a legislature that, having never formally participated in the decision to wage war in the first place, is able to secure itself against the political risks of doing so and lay the costs of the war at the feet of the executive. Fowler notes that "After the long nightmare of Vietnam" - but not during - "Congress reasserted its institutional prerogatives in international affairs. Lawmakers passed the War Powers Act in 1973, publicized a long list of CIA abuses, terminated funding for military operations in Southeast Asia, formed intelligence committees in both chambers to oversee clandestine activities, asserted greater control over the president's distribution of military aid, and trimmed defense spending." ${ }^{214}$ As was noted by Fisher ${ }^{215}$ and can be inferred from Howell and Pevehouse ${ }^{216}$, however, the War Powers Resolution can largely be seen as an effort to appear involved without actually imposing constraints upon the executive. Given the timing of all of the other provisions mentioned by Fowler, coming as they do, like the Bricker Amendment, after hostilities have ceased, the spirit of assertiveness in these measures is highly questionable.

For failings in a task of government - war making - which was specified in the Constitution to be the province of Congress, Lyndon Johnson so lost popularity that he chose not to seek reelection in $1968 .{ }^{217}$ Marking a further shift toward full

212 Presidential Approval Ratings-Gallup Historical Statistics and Trends, GaLlup, http:// www.gallup.com/poll/116677/presidential-approval-ratings-gallup-historicalstatisticstrends.aspx, (last visited Sept. 23, 2017).

213 Public Trust in Government: 1958-2014, Pew Res. Ctr., (Nov. 13, 2004) PewResearch. org, http://www.people-press.org/2014/11/13/public-trust-in-government/.

214 Louis Fisher, Presidential War Powers 71 (3d. ed., 2013).

215 Id.

216 See generally, William G. Howell \& Jon C. Pevehouse, While Dangers Gather: Congressional Checks on Presidential War Powers, (2007).

217 The role of Vietnam in Johnson's choice not to run has long been the subject of some controversy, with former officials in his administration denying that poll numbers on Vietnam played any role in the president's choice, e.g., James R. Jones, Behind L.B.J.'s Decision Not to Run in '68, N.Y. Times, Apr. 16, 1988. However, the popular consensus is that his unpopularity in 1968 played a significant role. I defer to the most common understanding here, with reference to JefF Shesol, Mutual Contempt: Lyndon Johnson, Robert Kennedy, and the Feud that Defined a Decade 545 (1998); Lewis L. Gould, 1968: The Election that Changed America 16 (2d ed., 2010), and Anthony J. Bennett, The Race for the White House from Reagan to Clinton: Reforming Old Systems, Building New Coalitions 160 (2013). 
executive accountability, unlike Democrats' brief loss of both houses due to the unpopularity of the Korean War, this time costs were not allotted along party lines but concentrated thoroughly on the executive. Johnson's party held a majority of the House and Senate throughout the Vietnam era by never less than fifty and fourteen seats, respectively. Adapting to the new institutional arrangement (military conflict as an executive venture), voters seem to have attached less responsibility for the war to the legislature than they did in 1950 and 1952. Vietnam also fits the description of undeclared conflicts as frequently long, costly endeavors that produce high numbers of American casualties and conclude in indecisive or unfavorable results. Despite an official casualty count of 58,220 U.S. soldiers and a financial cost of $\$ 738$ billion (2011\$), it achieved no lasting effect and failed to resist the establishment of a communist state ${ }^{218}$ The North Vietnamese and their allies in South Vietnam, the Vietcong, would repeatedly violate the terms of the peace, free from American reprisal or condemnation, and Saigon, capital of the South, would fall to North Vietnamese forces in 1975. In summary, the Vietnam War was a costly undeclared conflict with high fatalities conducted over a prolonged period and led to an unfavorable end, the blame for which fell squarely on the executive at little cost to legislators. Correlates of War ${ }^{219}$ lists it as a decisive loss for the United States, and Feaver and Gelpi ${ }^{220}$ code it as "Not Successful." It thus fits our model of undeclared conflicts quite well. While it would be unfair to say that legislators were not involved in the administration and conduct of the war on an ex post basis, their involvement again seems to track public opinion rather than start strong, bound by an ex ante sense of commitment to a conflict that they had authorized. Their neglect of the circumstance until after the conflict was fully underway discarded the possibility of debate over its merits and meant that responsibility for its initiation was not evenly borne by the two branches of government in the eyes of the public.

\section{iii. Persian Gulf War}

On August 2, 1990, under the leadership of Baathist dictator Saddam Hussein, Iraq invaded the neighboring gulf state of Kuwait. Iraq, heavily indebted and economically depressed after a deadly, protracted war against Iran had long perceived Kuwait as rightfully belonging to it and saw Kuwaiti oil reserves as a potentially valuable source of revenue. The Hussein regime cited Kuwaiti defection from OPEC oil production quotas as "economic warfare" and used it as a pretext for invasion. Decrying the act as unprovoked aggression, the United Nations Security Council imposed economic sanctions against Iraq. Under the leadership of President George H.W. Bush, U.S. forces were deployed to Saudi Arabia in preparation for repelling Iraqi troops from Kuwait. On January 17, 1991, the U.S. and a broad international alliance of 38 countries began a naval and aerial bombardment, followed by a ground invasion on February 24. By March 10, the Iraqi invasion had been effectively thwarted, Iraqi troops had been repelled back

218 U.S DeP't of Veterans Aff., America's Wars, (2017), https:/www.va.gov/opa/ publications/factsheets/fs_americas_wars.pdf.; Stephen DaggetT, Cong. Research Serv., RS22926, Costs of Major U.S. Wars 2 (2010).

219 Meredith Reid Sarkees \& Frank Wayman, Resort to War: 1816-2007 (2010).

220 Peter D. Feaver \& Christopher Gelpi, Choosing Your Battles: American CivilMilitary Relations and the Use of Force 140 (2004). 
across the border, and the more than half a million U.S. troops in the Gulf began to withdraw. Total U.S. casualties numbered 382 , a comparatively very small figure among post-World-War-Two undeclared conflicts. ${ }^{221}$

The clear cut victory of U.S.-led Coalition forces in the Persian Gulf War is one outstanding exception to the pattern of protracted, indecisive, and largely unsuccessful undeclared conflicts that characterize American military history in the post-World-War-Two era. ${ }^{222}$ Executed pursuant to the 1991 Authorization of the Use of Military Force Against Iraq Resolution ${ }^{223}$, it authorized the president to use armed forces to impose the terms of the relevant U.N. Security Council resolutions conditional upon his provision to House and Senate leaders adequate proof that all diplomatic measures at his disposal had been exhausted and his reportage on the progress of the conflict to those bodies at least once every sixty days. It conferred upon him no extraordinary powers nor any explicit limitations beyond explicitly stating the causes and justifications for its issuance. Nonetheless, it was an indisputable victory that invites us to consider what so differentiates this case from those preceding and following it.

The scale of the conflict and the relative strength of the combatants are the most readily available explanations. Certainly, were it a larger world power that had invaded, the conflict would likely have been longer and more difficult. However, if scale and relative strength were deterministic, U.S. intervention in Vietnam, Lebanon in 1983, the Libyan Civil War in 2011, and a litany of other minor interventions should presumably have been more decisive. That the Gulf War was a collaborative multilateral intervention conducted with broad international support should enhance commitment to a successful resolution. There again, by the same logic, the War in Afghanistan, with full NATO support, should have been similarly swift and decisive. And it cannot be discounted that, unlike Korea, Vietnam, Lebanon, Afghanistan, Iraq in 2002, and Libya in 2011, the Persian Gulf War was a clear case of a small, sovereign nation invaded by a foreign army with no recognized claims to any part of its territory. Lacking the ambiguities of intrastate conflicts, rebellions, and insurgencies, it presented clear delimitations and a well defined geographical boundary beyond which the invaders must be repelled, making the standard for victory apparent.

As to the role of the legislature, an argument could be made that Congress's moderate support for intervention (fifty-two percent in the Senate, fifty-seven percent in the House) ${ }^{224}$ was counterbalanced by the support of the United Nations and America's assumed responsibilities to that body. Furthermore, the AUMF issued by Congress, citing U.N.S.C. resolutions, ${ }^{225}$ explicitly noted the indiscretions and violations of international law by Iraq that were used to justify military force against it. More than some formal declarations of war (against Great Britain in 1812, Mexico in 1846, Spain in 1898, or Germany in 1917), the AUMF specifically

\footnotetext{
221 U.S. Dep’t of Veterans Aғғ., America's Wars (2017), https:/www.va.gov/opa/ publications/factsheets/fs_americas_wars.pdf.

222 Sarkees \& Wayman, supra note $21 \overline{9}$; FeAver \& Gelpi, supra note 220, at 140.

223 H.R.J. Res. 77, 102d Cong., 105 Stat. 3 (1991).

224 S.J. Res. 23, 107th Cong., 115 Stat. 224 (2001).

225 U.N.S.C. Res. 660 (1990); S.C. Res. 661 (1990); S.C. Res. 662 (1990); S.C. Res. 664 (1990); S.C. Res. 665 (1990); S.C. Res. 666 (1990); S.C. Res. 667 (1990); S.C. Res. 669 (1990); S.C. Res. 670 (1990); S.C. Res. 674 (1990); S.C. Res. 677 (1990).
} 
cited those actions taken by the targeted country, and it couched its actions more broadly within the authority of the United Nations. Even with a simple majority of support for the AUMF in both houses, Congressional involvement during the period was considerable. From the commencement of the one hundred and second Congress on January 3, 1991, to the withdrawal of U.S. troops on March 10, at least 68 bills and resolutions related to the conflict were introduced, including official condemnations of the Hussein regime and its actions against Kuwait, ${ }^{226}$ appropriations bills, ${ }^{227}$ provisions for returning veterans, ${ }^{228}$ measures regarding relations with Saudi Arabia and other allies, ${ }^{229}$ resolutions attempting to restrict the scope of the conflict to narrowly stated purposes ${ }^{230}$ resolutions calling for an international criminal trial of Hussein, ${ }^{231}$ and one attempt at a formal declaration of war, ${ }^{232}$ among others.

In sum, the Persian Gulf War enjoyed a beneficial combination of features that made it relatively easy to see through, and its success relative to other undeclared conflicts in the post-World-War-II era is probably best understood as a combination of these: an overwhelming military advantage against a small, underfunded and ill-equipped enemy; broad international support; a well defined standard of victory; and a very short duration, which left little room for the kind of political fatigue that has plagued more prolonged conflicts such as Vietnam and the War on Terror. Those who view formal declarations as incidental to the conduct of war may well argue that the Persian Gulf War is a textbook case of an AUMF sufficing for the achievement of a decisive and favorable resolution. Looked at very narrowly, with our focus restricted to the domestic political environment, that perspective would seem to bear the weight of the evidence. However, viewed in the broader context of these favorable circumstances, we see what good fortune is required before an undeclared conflict proves successful. To say that an undeclared conflict can succeed when all of the relevant forces align perfectly in leaders' favor is hardly indicative of the sort of robust political institution that we should want when undertaking a venture so costly and tenuous as war. Thus, while the Gulf War may be evidence that an undeclared conflict can be successful, it also arguably indicates the ideal and seldom observed conspiracy of circumstances that appear necessary to secure that success. Nonetheless, fair analysis dictates that I must acknowledge it as the most credible countersuit to our model of undeclared conflicts.

\section{iv. War in Afghanistan and Iraq War}

The War in Afghanistan that began in the fall of 2001 was the first instance since World War II in which the United States engaged in a significant armed conflict on its own behalf rather than as an intervention into the internecine conflicts of another region. After the attacks of September 11th, the United States, under the leadership of President George W. Bush and with the joint collaboration of the

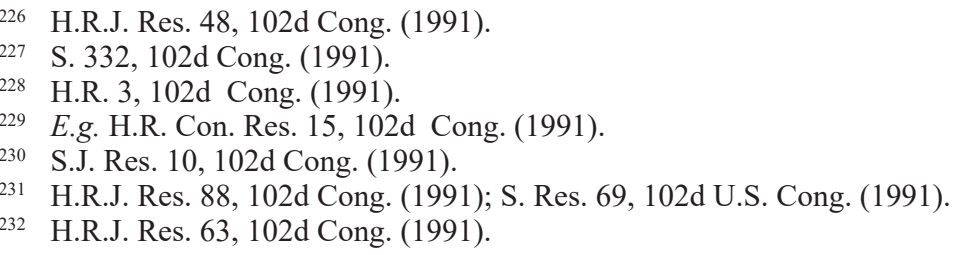


United Kingdom, invaded Afghanistan for the stated purpose of seeking out all of those responsible for those atrocities and unseating the Taliban regime which had protected and fostered them. Consensus held at the time and further developments substantiated the deep interconnectedness between Al-Qaeda, led by September 11th architect Osama bin Laden, and the Taliban under the leadership of Mullah Omar. Though Afghanistan was largely held to have been rendered a failed state through protracted civil war, the unrecognized Taliban government was seen as the predominant power within Afghanistan and was the closest it had to a functioning system of government.

Nonetheless, when President Bush sought authorization from Congress for military action, he neither requested nor received a formal declaration of war or an AUMF limiting the executive to action against certain individuals, organizations, or nations. The AUMF that was granted was entirely open-ended, delegating to the president unilateral discretion to take the pursuit of justice across any national borders and against any parties he deemed responsible for the attacks. In its own words, "[T]he President is authorized to use all necessary and appropriate force against those nations, organizations, or persons he determined planned, authorized, committed, or aided the terrorist attacks that occurred on September 11, 2001. ${ }^{233}$ Thus, America's first experience using an AUMF for a large-scale and protracted conflict provided little scope for congressional oversight and legislative accountability. It would follow that authorization with another in 2002 for the use of military force against Iraq, which, in a war of broadening scope against any and all actors deemed to support terrorism, was seen by the Bush administration as the next logical choice for invasion.

Contrary to all formal declarations by the United States, the motivating clause of the 2001 AUMF makes no mention of Congress except to detail what Congress authorizes the executive to do. It does not explicitly commit any of the nation's resources to its control. By the very nature of the AUMF it is asserting the position not of the ultimate authority with respect to war, with the executive as manager thereof, but a far more delegative role. It has not established and has, in fact, resisted attempts to establish rigorous reporting by the executive. In the deliberations over the 2001 AUMF, Rep. John Tierney (D-MA6) moved to require a report from the president on executive actions under the resolution every sixty days. The movement was quickly dispelled by a majority of the House. ${ }^{234}$ That proposal does not seem to have been entirely in vain: it would make it into the 2002 AUMF against Iraq. ${ }^{235}$ Its ineffectiveness at inspiring congressional involvement in and oversight of the war, however, is indicated by a dearth of legislative oversight hearings in the ensuing years.

Thomas E. Mann and Norman J. Ornstein, writing in late 2006, note the collapse of legislative monitoring in foreign policy even in the first five years of the War on Terror: "In the past six years... congressional oversight of the executive across a range of policies, but especially on foreign and national security policy, has virtually collapsed. The few exceptions, such as the tension-packed Senate hearings

33 S.J. Res. 23, 107th Cong., 115 Stat. 224 (2001).

234 Jennifer K. Elsea \& Matthew C. Weed, Cong. Research Serv., RL31133, Declarations of War and Authorizations for the Use of Military Force: HistoricAl BACKGROUND AND LEGAL ImPLiCATIONS (2014).

235 H.J. Res. 114, 107th Cong., 116 Stat. 1498 (2002). 
on the prison scandal at Abu Ghraib in 2004, only prove the rule. With little or no midcourse corrections in decision-making and implementation, policy has been largely adrift." ${ }^{236}$ Describing the legislative disposition: "oversight of foreign policy has taken the form of 'fire alarm' hearings, responding to scandals or crises, rather than of 'police patrols,' designed to prevent problems before they occur." More broadly, they note that throughout the post-World-War-Two period (the precise range within which undeclared military engagements rose in frequency), there was a collapse in the institution of congressional oversight of foreign affairs (military operations in particular) that once saw legislators frequently challenging even presidents of their own party in the name of checks and balances. A longtime Senate staffer is quoted as saying that "the Senate Armed Services Committee held no hearings specifically on operations in Afghanistan in 2003 and 2004, and only nine on Iraq [excluding the prisoner abuse matter] in that period-less than 10 percent of its total hearings. The House Armed Services Committee held only one hearing on Afghanistan in 2003 and 18 on Iraq during 2003-2004-less than 14 percent of its total number of hearings. The Senate Foreign Relations Committee spent 19 percent of its time on those two countries." Kriner and Shen note the greater propensity of legislators to make floor speeches when military casualties from their state or district are high, but this effect on speeches has not observably translated into committee actions, legislative checks on executive military discretion, nor legislative demands for more control over military and defense policy. ${ }^{237}$ The New York Times and Washington Post would later apologize to their readers for failing to pursue an understanding of the rationale behind the Iraq War's AUMF, but according to Fowler "[ $t$ ]he papers' failure to a large extent reflected the lack of authoritative sources on Capitol Hill that publicly reviewed the war and offered alternative views to the Bush administration's version of events." 238

Even in the 2006 midterm elections, when voters listed the Iraq War as one of the two most important issues, their opposition to the war manifested as largely anti-Bush in nature, voting out Republicans as a statement against the Republican president. CNN exit polls showed fifty-seven percent opposition to the Iraq War and fifty-eight percent disapproval of George W. Bush. ${ }^{239}$ Thirtyfive percent of voters listed the Iraq war as "Extremely Important" to their vote, thirty-two percent as "Very Important," and twenty-one percent as "Somewhat Important." In the same poll, thirty-six percent of voters reported voting to "Oppose Bush" with twentytwo percent voting to "Support Bush" and thirtynine percent reporting that Bush was not a factor in their vote. ${ }^{240}$ In a January 2007 Gallup poll, fifty-three percent of those who said that Iraq had gone worse than expected said they blamed Bush

236 Thomas E. Mann \& Norman J. Ornstein, When Congress Checks Out, Foreign Aff., (Nov./Dec. 2006), https://www.foreignaffairs.com/articles/united-states/2006-11-01/ when-congress.

237 Douglas Kriner \& Francis Shen, Responding to War on Capitol Hill: Battlefield Casualties, Congressional Response, and Public Support for the War in Iraq, 58 Ам. J. Pol. SCI. 157 (2014).

238 Linda L. Fowler, Watchdogs on the Hill: The Decline of Congressional Oversight of U.S. Foreign Policy 61 (2015).

239 Exit polls: Bush, Iraq key to outcome, $\mathrm{CNN}$, ( Nov. 8, 2006), http:// www.cnn.com/2006/POLITICS/11/08/election.why/.

240 America Votes 2006: Exit Polls, CNN, https://edition.cnn.com/ELECTION/2006/pages/ results/states/US/H/00/epolls.0.html, (last visited Sept. 23, 2017). 
a "Great Deal," compared with forty-one percent saying the same of Iraqi political leaders and Secretary of Defense Donald Rumsfeld followed by Vice President Dick Cheney at thirty-three percent, U.S. intelligence agencies at twenty-six percent, the U.S. news media at twentyfour percent, and U.S. military leaders in Iraq at thirteen percent. ${ }^{241}$ Congress was Congressional Republicans' approval rating, at roughly fifty percent, could not overcome that of President Bush, which hovered in the thirties. ${ }^{242}$ With Bush no longer on the ballot in 2008, however, the new Democratic majority did not seem to be similarly punished in the next election for presiding over the 2007 Iraq "surge" nor for the decade since of continued military presence in Afghanistan and Iraq. The war was, again, a largely executive venture in public opinion.

Consistent with a pattern, both of these conflicts proved to be long, ambling projects carried out at immense cost and without a clear or decisive resolution. The War in Afghanistan has been the single longest military engagement in the history of the United States, officially dating over thirteen years from the time of U.S. invasion until NATO officially handed power over to the Afghan government in December 2014. Correlates of War lists it initially as an interstate war but codes it as having "transformed into another type of war." From there, it was reclassified as an "Extra-State War" (one conducted between a state and non-state actor) and is listed as ongoing as of December 31, 2007. ${ }^{243}$ Since then, a residual force of U.S. troops has remained in-country and continues to conduct airstrikes and special operations; both NATO and the CIA have proceeded to establish an indefinite presence there; and the withdrawal of U.S. troops has been repeatedly pushed back in the face of instability. ${ }^{244}$ The same descriptors are applied to Iraq, in sequence. There, the vacuum created by the fall of Saddam Hussein's regime led to the rise of the Islamic State and spread into neighboring, war-torn Syria. Despite the formal end of the Iraq War in December of 2011, U.S. Special Forces were again called upon to conduct special operations and train Kurdish resistance forces. ${ }^{245}$ In a speech before NATO at Warsaw, Poland, in July of 2016, President Obama described the state of a quasiwar that he said would last beyond his time in office, was not definitively successful, and offered no clearly foreseeable resolution what the Washington Post called "a

${ }^{241}$ Presidential Approval Ratings-George W. Bush, Gallup, http://www.gallup.com/ poll/116500/presidential-approval-ratings-george-bush.aspx, (last visited Sept. 27, 2017).

242 Lydia Saad, Congress' Approval Rating Ties Lowest in Gallup Records, GalluP, May 14, 2008, http://www.gallup.com/poll/107242/congress-approval-rating-ties-lowestgalluprecords.aspx.

243 Meredith Reid Sarkees \& Frank Wayman, Resort to War: 1816-2007 (2010).

244 Tim Craig, Nato Hopes to Keep a Base in Afghanistan, U.S. General Says, Wash. Post, May 23, 2015, https://www.washingtonpost.com/world/nato-hopes- tokeepa-long-term-base-in-afghanistan-us-general-says/2015/05/23/d4f6a25c-0157-11e58c77bf274685eldf_story.html; Matthew Rosenberg \& Michael D. Shear, In Reversal, Obama Says U.S. Soldiers Will Stay in Afghanistan to 2017, N.Y. Times, Oct. 15, 2015, http://www.nytimes.com/2015/10/16/world/asia/obama-troopwithdrawal-afghanistan. $\mathrm{html}$ ?_r $=0$.

245 Spencer Ackerman, U.S. Military Special Forces Pictured Aiding Kurdish Fighters in Syria, GuARDian, May 26, 2016, https:/www.theguardian.com/world/2016/may/26/ usmilitary-photos-syria-soldiers-fighting-isis. 
new kind of endless war." ${ }^{246}$ When the Obama administration sought congressional approval for actions against the Islamic State in 2014, The New York Times reported that "congressional leaders, who met with Mr.Obama about Iraq in June, have explicitly told them that Mr. Obama need not go to Congress to authorize military action, ${ }^{247}$ prompting Senator and later Vice-Presidential nominee Tim Kaine (DVA) to pen an opinion article in The Washington Post, commenting that "This is not about an imperial presidency. It's about a Congress that's reluctant to cast tough votes on U.S. military action." 248

\section{CONCLUSION}

The history of American military engagements can be read as a story of two very different kinds of endeavors: one, formally declared wars, which have been thoroughly prosecuted and invariably successful; the other, undeclared wars, the record of which has been considerably mixed. The paradox of the postWorld-WarTwo era, in which the United States has has simultaneously been recognized as the world's preeminent superpower but at the same time suffered a long series of prolonged, indecisive, and unsuccessful conflicts, suggests that the source of its troubles is not a matter of sheer military strength. Politicians and pundits have resorted to calling America's modern military actions "a new kind of war" in which the old rules do not apply, in which clear victory can never be expected, and which may well last decades or a generation. The cryptic nature of these characterizations, however, invites us to look for underlying changes in the institutional structure of American warfare, both military and political. The most politically relevant of these is America's abandonment of formal declarations of war.

Formal declarations, this theory has argued, are much more than the outmoded technicalities that they are often dismissed as being. By requiring the explicit, formal endorsement of two branches of government, they have the effect of committing politicians in both branches to the outcome of the war, enhancing legislative involvement and improving the political will to achieve a favorable and decisive outcome. By limiting politicians' capacity to shift credit and blame at will, declarations better ensure that politicians have a reputational stake in the outcome, inducing them to exert more effort in the conflict's political administration. In this sense, they carry commitment value analogous to a formal pledge or written contract.

The result is a stark contrast in the two models' records of success, with all six of America's formally declared wars having ended on clearly favorable terms,

246 Greg Jaffe \& Michael Birnbaum, With a Hint of Regret, Obama Describes New Kind of Endless War, WASH. Post, July 9, 2016, https://www.washingtonpost.com/politics/ with-a-hint-of-regret-obama-describes-new-kind-of-endless-quasi-war/2016/07/09/ b9fdacb2-4624-11e6-bc99-7d269f8719b1_story.html.

247 Julie Hirschfield Davis, Neither Obama Nor Congress Seems Eager for a Vote on Military Action in Iraq," N.Y. Times, Aug. 19, 2014, at A15.

248 Tim Kaine, Congress Has a Role in U.S. Military Action in Iraq, Wash. Post, (June 24, 2014), https://www.washingtonpost.com/opinions/tim-kaine-congress-has-a-roleinus-military-action-in-iraq/2014/06/24/77ec1776-fbc8-11e3-b1f4-8e77c632c07b_story. html. 
a distinction enjoyed by only one out of five major undeclared conflicts in the postWorld-War-Two era. The Persian Gulf War aside, the trend appears to be in the direction of progressively less legislative involvement and accountability over time. The Korean War saw initial legislative deference that was quickly, if briefly, punished by voters. The Vietnam War saw no such punishment, with the majority party-Democrats - retaining considerable control of the legislature at all times throughout a strikingly unpopular and widely protested war. In both cases, we saw an executive-Truman, then Johnson-bear such undivided responsibility for the war in the public eye that despite starting with eighty-seven percent and seventynine percent approval, respectively, neither was able to seek reelection. Only in the 2006 midterm elections does the unpopularity of a war seem to have played heavily into voter preferences in a way that lasted more than one congressional term, but the argument for legislators' partisan association with President Bush being the dominant influence there is strong. Thus, with presidents being punished for wars in more dramatic ways than legislators, we must consider the possibility that the view of war as a primarily executive undertaking is being cemented in public opinion, contrary to the dictates of the Constitution. With a small and dwindling percentage of the electorate having been alive the last time the United States formally declared war, it is reasonable to assume that voter expectations for legislative involvement in the political tasks of warmaking will continue to be significantly diminished relative to previous eras.

A lingering question that these case studies invite is what motivates the executive branch's repeated willingness to pursue such endeavors. The legislature's desire to distance itself from wars of choice is in keeping with our understanding of politicians as risk-averse. Why presidents choose to get involved in such conflicts of their own accord despite the great costs it has imposed on their predecessors is less clear, though the assumption of risk aversion for the executive should not necessarily be abandoned. It is possible that the executive faces such different incentives and expectations in voters' eyes that the safe bet for presidents is to err on the side of engaging in conflict, particularly since the passage of the War Powers Resolution gave presidents an explicit window within which they could act, free from accountability to Congress. Such provisions may make executives more likely to receive blame for inaction on an ex post basis, making military engagement the risk-averse option. This consideration is speculative, however, and is sufficiently intricate to deserve fuller analysis of its own.

The debate over formal declarations of war has historically been divided between, on the one hand, those who view them as archaic, hyper-formalist obstacles to swift, executive-led military action and, on the other, those who view them as proper checks on executive power that are necessary to ensure proper political representation in decisions over war and obediance of constitutional strictures. Opponents of declarations prioritize efficiency in military action; proponents cite ideological values, diplomatic propriety, and careful restraint. This article has put forth a unique institutional viewpoint on the subject, arguing that declarations, through the incentives they establish, have a significant effect on the political conduct of the war that makes expedient victory more likely. From a survey of historical arguments for declarations, this appears to be the first to propone them on the grounds of enhancing the likelihood of military victory. Marrying a respect for the value of constitutionally limited government with a focus on broader strategic considerations, it is arguably the most efficiency-oriented perspective on either side of the debate, if efficiency is broadened to include the achievement of victory in war 
rather than simply the lowest cost means of entering a war. Whether and how the implicit Coasean bargain between the two branches can be overcome in a manner that restores the intent of the Constitution's framers is a narrower but more daunting subject of future inquiry troubled by perverse political incentives, coordination problems, and voters' own rational ignorance. 